\title{
LA TECNOLOGÍA ALFARERA COMO HERRAMIENTA DE ANÁLISIS HISTÓRICO: REFLEXIONES SOBRE LOS DENOMINADOS "PRISMAS CERÁMICOS"
}

\section{POTTERY TECHNOLOGY AS A TOOL FOR HISTORICAL ANALYSIS: REFLECTIONS ON THE SO-CALLED 'CERAMIC PRISMATIC KILN FURNITURE'}

\author{
JOSÉ MARÍA GUTIÉRREZ LÓPEZ* \\ ANTONIO MANUEL SÁEZ ROMERO** \\ MARÍA CRISTINA REINOSO DEL RÍO*
}

\begin{abstract}
Resumen: Estudiamos en este trabajo aspectos tipológicos, funcionales y cronológicos de una serie de elementos cerámicos de morfología prismática o semilunar tradicionalmente asociados a tareas alfareras, empleados fundamentalmente como soportes o separadores. Aunque conocidos en la bibliografía hispana con anterioridad, se trata de una categoría de enorme interés para el análisis histórico pero que hasta el momento, había recibido una atención reducida, por lo que ahora planteamos una sistematización de su evolución morfológica, una aproximación diacrónica a su dispersión peninsular y también aportamos algunas consideraciones sobre la relación de estos prismas con otros procesos de transferencia tecnológica entre los colonos fenicios y las sociedades indígenas de Iberia. Como complemento a este análisis de la evidencia peninsular, se realiza una contextualización a escala mediterránea del uso de elementos auxiliares en los talleres alfareros antiguos, intentando rastrear así los orígenes de los prismas peninsulares.
\end{abstract}

Palabras clave: Útiles de alfarero, producción cerámica, Iberia, Fenicios, tecnología, prismas

\footnotetext{
* Museo Histórico Municipal de Villamartín. Avda. de la Feria s/n. 11650-Villamartín (Cádiz). Correo-e: museovillamartin@hotmail. com, mcristinareinoso@yahoo.es
}

\begin{abstract}
Typological, functional and chronological issues of ceramic kiln furniture with prismatic and «crescent shaped» morphologies (traditionally associated with pottery production mainly as supports or spacers) are studied in this paper. Although known in regional foregoing historiography, this ceramic tools so far have received limited attention but are considered really interesting for historical analysis, so a first systematization of their morphological evolution and a diachronic approach to their diffusion in Iberian peninsula is proposed. Also we make some considerations about the relationship of these stilts with other technology-transfer processes between phoenician-punic settlers and indigenous societies in ancient Iberia. To complement this analysis of the archaeological evidence of Iberian sites we finally expose a contextualization of the finds in the Mediterranean focusing attention on the use of auxiliary equipment in ancient pottery workshops, trying to trace the origins of this kind of kiln furniture found in Iberian peninsula.
\end{abstract}

Key words: Kiln furniture, pottery production, Iberia, Phoenicians, technology, stilts

\footnotetext{
** Área de Arqueología, Universidad de Cádiz. Departamento de Historia, Geografía y Filosofía. Avda. Dr. Gómez Ulla, s/n. 11003-Cádiz. Correo-e: antonio.saez@uca.es
} 


\section{INTRODUCCIÓN: PROBLEMÁTICA GENERAL}

En la actualidad resulta communis opinio el papel protagonista que el mundo fenicio ejerció en la introducción del torno alfarero, en el aumento de complejidad de las estructuras de combustión (hornos de tiro vertical y doble cámara) y en general en el desarrollo de procesos de producción cerámica industrializados en el mundo indígena tartésico, en un fenómeno de transferencia tecnológica que debió desarrollarse rápidamente desde casi los inicios de la propia implantación de talleres cerámicos en los asentamientos coloniales (Ramón 2006: 199). No obstante, es aún bastante notoria la carencia de conocimientos sobre esos hornos alfareros, sus dependencias y sus procesos de producción, a pesar de que debieron ser abundantes los centros productores implantados tanto en los grandes núcleos tartésicos-turdetanos del Bajo Guadalquivir como en otros asentamientos de orden secundario. En este trabajo nos centraremos de forma diacrónica en un aspecto concreto de esta interesante interacción cultural-tecnológica, desde los inicios del proceso hasta su disolución con la entrada en escena de Roma, focalizando nuestros esfuerzos en el estudio de los soportes cerámicos relacionados específicamente con los procesos de cocción, secado y almacenaje desarrollados en estos alfares del extremo occidental del Mediterráneo.

La presencia de elementos de sección triangular (comúnmente denominados prismas cerámicos) en diversos asentamientos fenicios del sur peninsular no ha pasado precisamente desapercibida para un buen número de casos, si bien paradójicamente no han recibido la atención monográfica que su abundancia y aparente funcionalidad parecen reclamar desde hace algunas décadas. Estos ítems han sido tradicionalmente interpretados como útiles vinculados a la producción cerámica, asistentes en las funciones de secado y/o cocción, y fueron prontamente dados a conocer a través de los resultados de las excavaciones realizadas en la desembocadura del río Guadiaro (Schubart 1987). En este emplazamiento de cronología arcaica (ss. VIII/VI a.n.e.), cuya filiación fenicia o tartésica ha venido siendo discutida desde su publicación preliminar (Schubart 1987: 208209), se vertieron las primeras consideraciones específicas sobre este tipo de elementos:

[...] se encuentra también un tipo de soporte, del cual existe una serie de ejemplos. Se trata de un objeto aún no identificable, cuyo cuerpo, macizo, muestra una sección triangular, terminando en dos extremos planos. [...] Suponemos que estos soportes tenían una función práctica, tal vez en los alfares para sostener el relleno de un horno, tal vez también en la explotación de las salinas o en relación con otras actividades [...] (Schubart 1987: 206).

De este modo, comenzaban a plantearse interrogantes clave sobre los orígenes de este tipo de soportes y su probable relación con las alfarerías fenicias del sur de Iberia sin que, por entonces, pudiesen vislumbrarse aún argumentos para la discusión de su verdadera dimensión tecnológico-funcional y su evolución morfológica.

Empezaba por entonces en la costa de Málaga el Proyecto Guadalhorce, centrado en la investigación del asentamiento fenicio del Cerro del Villar, en el cual las primeras investigaciones de los años sesenta ya habían constatado el papel de las actividades alfareras de época fenicio-púnica (Arribas y Arteaga 1975: 14). Las campañas de excavación desarrolladas en los ochenta e inicios de los noventa del siglo XX permitieron ampliar el número de hallazgos diáfanos de estos ítems en contextos alfareros, aportando los hallazgos del Sector 3/4 del Cerro del Villar (Barceló et al. 1995: 147-183, Aubet et al. 1999) múltiples evidencias en contexto vinculadas a los procesos productivos de un taller de época arcaica avanzada (primera mitad del s. VI a.n.e.), convirtiendo por lo tanto a priori a estos prismas en buenos indicadores de la presencia de actividades alfareras en los yacimientos en que se encuentran presentes. Sin embargo, y a pesar del enorme avance que suponían estas excavaciones por el método de tratamiento de la información, los soportes prismáticos recibirían una atención secundaria dentro del elenco de objetos ligados a las tareas productivas, como parte de los instrumenta típicos de estos centros alfareros. En cualquier caso, la documentación explícita aportada por los restos del taller del siglo VI a.n.e. permitía en el caso del Villar realizar una caracterización funcional mucho más precisa que en el cercano Guadiaro, vinculando en esta ocasión los soportes a tareas precisas:

Relacionados directamente con el proceso de cocción se ha identificado la función de los items denominados prismas, por otro lado, frecuentemente documentados en yacimientos fenicios peninsulares. [...] Su función sería la de ejercer de separadores entre las cerámicas al ser introducidas en la cámara de cocción, con el fin de evitar los riesgos de roturas y estallidos que se pueden producir por la proximidad entre las vasijas debido a las contracciones y dilataciones que las arcillas sufren al ser sometidas a altas temperaturas. La misma función tendrían otros medios de producción identificados como 
cuñas, consistentes en pequeñas piezas de cerámica de forma triangular o rectangular. Además de estos datos etnográficos, los análisis fisicoquímicos realizados en alguna de estas piezas parecen confirmar su papel dentro del proceso de cocción, ya que muestran claros indicios de haber estado expuestos repetidamente a altas temperaturas, lo que indicaría que no estarian destinados a una posterior comercialización, sino que su uso se vincularía, únicamente, al proceso de producción (Aubet et al. 1999: 289-290).

Se daba así un significativo paso adelante en la definición funcional y cronológica de los prismas arcaicos pero, al mismo tiempo, se abría la puerta a la necesidad de profundizar en aspectos como su origen tecnológico, su difusión y evolución (de haberla) en el contexto de los talleres fenicios occidentales e indígenas.

En otros ámbitos peninsulares relacionados con la producción cerámica antigua habían sido identificados en las últimas décadas otros elementos relacionados con tareas parecidas vinculadas a funciones de soporte, los cuales mostraban en muchos casos rasgos tipológicos que apuntaban la posibilidad de establecer relaciones entre todos estos grupos de útiles alfareros. Sin embargo, la configuración tosca de estos prismas, hechos habitualmente a mano, y su escasa vistosidad, dentro de los conjuntos vasculares aportados por la excavación de los alfares, parecía condenar casi siempre su estudio a breves notas o consideraciones generales, fijando en ellas una posición general a favor de su uso prioritariamente alfarero pero normalmente sin profundizar más allá en sus relaciones tipológicas, funcionalidades alternativas u orígenes de su uso en la zona de hallazgo. Por tanto, podemos decir que su investigación se encuentra en un estado aún incipiente, especialmente en lo referido a su encuadre morfo-funcional, a la definición de las tradiciones alfareras en la que se insertan, su contextualización en el ámbito mediterráneo y a las evoluciones formales advertidas en algunas de las series de prismas conocidas. Del mismo modo, debemos resaltar que, hasta el momento, si bien los prismas arcaicos han recibido una escasa atención, sus formas evolucionadas de época púnica o helenística han tenido un protagonismo aún menor, por lo que el tratamiento diacrónico de estos útiles y procesos alfareros es por el momento una asignatura pendiente.

En estas circunstancias y partiendo de los planteamientos referidos, nuevos hallazgos de estos prismas en diversos contextos peninsulares nos han llevado a plantearnos la necesidad de generar un primer marco de referencia tipológico diacrónico para estos ítems alfareros, intentando responder en lo posible a algunas de las preguntas tanteadas décadas atrás y a la propuesta de nuevos niveles de exigencia a la potencial información aportada por los soportes. Además de insertar estas piezas prismáticas en su contexto estratigráfico y cronocultural, su análisis tipológico y funcional permite plantear algunas consideraciones en el marco peninsular acerca del origen, difusión y evolución de este tipo de posibles útiles alfareros que, por el momento, no han recibido la necesaria atención por parte de la comunidad investigadora. Así pues, realizaremos un repaso diacrónico a la dispersión de estos prismas y su relación con los centros de producción cerámica fenicios e indígenas de la Iberia del primer milenio antes de la Era, planteando nuevas hipótesis sobre su posible vinculación directa con la tecnología alfarera de tradición semita y la difusión del torno alfarero y los hornos de doble cámara en ámbito tartésico-ibérico.

\section{EVOLUCIÓN TIPOLÓGICA Y PROPUESTA DE DATACIÓN DE LOS PRISMAS CERÁMICOS}

Uno de los aspectos básicos en los que no se ha profundizado demasiado en relación al estudio de estos ítems resulta el apartado de la terminología, probablemente dada la inexistencia hasta ahora de un verdadero conjunto orgánico tipificado y diferenciado de otras clases cerámicas. Ha arraigado en la bibliografía que ha tratado esta problemática el uso del término prisma, de matriz latina, que se define según el Diccionario de la Real Academia Española, específicamente en lo referido a cuestiones geométricas, como "Cuerpo limitado por dos polígonos planos, paralelos e iguales que se llaman bases, y por tantos paralelogramos cuantos lados tenga cada base. Si estas son triángulos, el prisma se llama triangular" (DRAE, consulta 02.02.2011). Resulta evidente que la aplicación de esta definición a las piezas que analizamos se deriva del estudio de los prismas de época arcaica como los recuperados en Guadiaro o en Cerro del Villar, cuyo ajuste a estos parámetros geométricos es exacto. Sin embargo, otros modelos que evolucionaron a partir de ellos presentan características geométricas algo distintas que, en algunos casos (como la falta de aristas que definan planos), no pueden incluirse estrictamente en esta acepción si bien parece que la esencia primigenia de esta estructura prismática perduró en el esquema evolucionado. Por ello, dado el cierto arraigo historiográfico del término prisma y que su estructura básica corresponde al esqueleto generador de los tipos evolucionados, 
consideramos la denominación válida en términos generales, aunque será necesario matizar a través de la tipología concreta que proponemos en estas páginas.

La discusión sobre la terminología asociada a los útiles vinculados a los procesos alfareros (especialmente a la colocación de las piezas durante la cocción) se había desarrollado también fuera del marco peninsular, aunque éste quedó desconectado de este debate a nivel mediterráneo (Cracolici 2003: 19-24). Trascendiendo la cuestión meramente etimológica, la reciente discusión terminológica se ha centrado más en la relación de la nomenclatura con sus implicaciones funcionales. Así, se integran formas similares a los prismas peninsulares en conjuntos de materiales mucho más amplios y heterogéneos pero unidos por su uso dentro de las tareas de apilamiento y cocción de las cerámicas. Destaca la riqueza de documentación y el gran desarrollo alcanzado por estos estudios en el mundo griego oriental y magnogreco, con una relativamente amplia nómina de trabajos monográficos sobre la cuestión (Kalogeropoulou 1970, Papadopoulos 1992 y 2003) e incluso algunas tesis doctorales específicas (Cracolici 2003). En este último trabajo se ha recogido el debate anterior, sintetizando las denominaciones aplicadas a estos ítems en la investigación anglosajona (kiln firing supports, kiln furniture, kiln props, stilts), francesa (isolateurs) e italiana (principalmente sostegni, distanziatori o separatori). Todas ellas inciden en general en la labor principal atribuida a estos elementos: separar las piezas cerámicas durante la cocción para evitar problemas -especialmente con los barnices- y, en general, ayudar a estabilizar las piezas apiladas, sirviendo de soporte, o cuña en su caso, para ajustar las columnas de vasos de cualquier tamaño o incluso los elementos de mayor tamaño o materiales constructivos (Cracolici 2003: 19). Este mismo autor ha señalado asimismo que el uso de estos elementos auxiliares "[...] sembra motivato principalmente dall'esigenza di migliorare la produzione del punto di vista quantitativo, ottimizzando la capacità di carico della fornace" (Cracolici 2003: 130). En cualquier caso, la nota común reside en su identificación como elementos de soporte dentro de las tareas de carga del horno, si bien esta denominación no parece poder trasladarse tal cual al caso de los prismas extremo-occidentales dada la escasa información que disponemos sobre su uso concreto.

Por todo ello, parece prudente por el momento englobar estos útiles en una terminología genérica (prisma), reservando las consideraciones funcionales para otros niveles más profundos que su propia denominación. Teniendo en cuenta esta limitación se imponía por tanto establecer una ordenación tipológica de estos prismas, tarea que será el objetivo esencial en este apartado. Así pues, nos ocuparemos del examen morfológico de estos prismas a través de su encuadre en una nueva tipología general diseñada desde una óptica diacrónica, así como del análisis con un tono similar de la extensión del fenómeno en el seno de los talleres alfareros prerromanos de la antigua Iberia, explorando paralelamente las posibles vías de introducción, difusión y evolución de las formas y usos vinculados a los prismas. Como complemento a esta información peninsular realizaremos finalmente una panorámica del estado de los estudios de este tipo de elementos subsidiarios de la producción cerámica en otros ambientes mediterráneos, no sólo del mundo púnico, lo que nos permitirá subrayar los déficits de la investigación sobre los prismas ibéricos y aportar significativos datos sobre los orígenes de esta tecnología y su posible interacción con otras tradiciones artesanales.

\section{BREVES APUNTES SOBRE TIPOLOGÍA Y CRONOLOGÍA DE LOS PRISMAS}

El primer paso imprescindible en esta aproximación a la problemática de los prismas peninsulares resultaba la generación de un marco tipológico que, sobre la base de la documentación disponible, fijase los principales grupos morfométricos y sus variables internas, permitiendo así una mayor concreción que la determinada por el término genérico prisma. Como expusimos, para la configuración de estos tipos descartamos una denominación con referencias funcionales, como la desarrollada en otros ámbitos mediterráneos, limitándonos a ordenar las principales familias siguiendo esencialmente un criterio morfológico, aunque intentando compaginar este aspecto con la dimensión cronológica del uso de dichos elementos auxiliares. Un primer acercamiento a su estudio, a partir de la documentación publicada de la treintena de localizaciones (tab. 1) tratadas en los apartados siguientes (v. infra), nos ha permitido definir la existencia de tres grupos principales de estos elementos subsidiarios de las actividades artesanales (tab. 2), cuyas características morfométricas, técnicas y cronológicas han sido ampliamente tratadas en trabajos precedentes a los que remitimos (Gutiérrez et al. 2012). TIPO A: Se trata aparentemente del prototipo inicial de prisma, de cronología arcaica, implantado en la fase inicial de la producción alfarera de tradición oriental desarrollada en suelo peninsular. Asimismo corresponde al diseño más básico y de líneas más 
Tabla 1. Hallazgos de prismas documentados en Iberia, indicando cuestiones como la tipología o la relación directa con hornos alfareros.

\begin{tabular}{|c|c|c|c|c|c|c|c|}
\hline $\mathrm{N}^{\mathrm{o}}$ & YACIMIENTO & $\mathrm{N}^{\circ *}$ & TIPO & $\begin{array}{l}\text { CRONOLOGÍA } \\
\text { CONTEXTO A.N.E. }\end{array}$ & $\begin{array}{l}\text { BIBLIOGRAFÍA } \\
\text { PRISMAS }\end{array}$ & $\begin{array}{c}\text { HORNOS } \\
\text { ALFAREROS }\end{array}$ & $\begin{array}{l}\text { BIBLIOGRAFÍA } \\
\text { HORNOS }\end{array}$ \\
\hline 1 & Torrevieja & 9 & A-B & Siglos VII / VI & Inéditos & - & - \\
\hline 2 & Chorreras & 1 & A & $\begin{array}{l}\text { Siglos VIII / } \\
\text { inicio VII }\end{array}$ & $\begin{array}{c}\text { Martín Córdoba et al. } \\
2006\end{array}$ & Sí & Ruescas y Ramírez 2010 \\
\hline 3 & Montilla (Guadiaro) & 11 & A & $\begin{array}{l}\text { Siglos VIII / } \\
\text { inicio VII }\end{array}$ & Schubart 1987 & - & - \\
\hline 4 & Ategua & 3 & A & Siglo VII & López Palomo 2008 & - & - \\
\hline 5 & Cerro de los Infantes & 1 & A & Siglo VII & Mendoza et al. 1981 & Sí & Contreras et al. 1983 \\
\hline 6 & Cerro del Villar & $<146$ & A & Siglos VIII / VI & Barceló et al. 1995 & Sí & Aubet et al. 1999 \\
\hline 7 & Huertas de Peñarrubia & 4 & A & Siglo VII & García Alfonso 1995 & - & - \\
\hline 8 & Malaka & $<1$ & A & Siglo VI & Gran Aymerich 1991 & Sí & $\begin{array}{c}\text { Arancibia y Escalante } \\
2010\end{array}$ \\
\hline 9 & La Pancha & varios & ¿A? & $\begin{array}{l}\text { Siglos VII / } \\
\text { inicio VI }\end{array}$ & $\begin{array}{c}\text { Martín Córdoba et al } \\
2006\end{array}$ & Sí & $\begin{array}{c}\text { Martín Córdoba et al. } \\
2006\end{array}$ \\
\hline 10 & Los Algarrobeños & varios & ¿A? & Siglos VI / V & Recio Ruiz 2002 & - & - \\
\hline 11 & Acinipo & Indet. & ¿A? & Orientalizante & González et al. 1995 & - & - \\
\hline 12 & Huelva (Puerto-9) & 1 & A & Inicios siglo VI & Fernández Jurado 1989 & - & - \\
\hline 13 & Tejada la Vieja & 1 & A & Siglos VI / V & Fernández Jurado 1987 & - & - \\
\hline 14 & Canto Tortoso (Gorafe) & 2 & A & Siglo VI & González et al. 1995 & - & - \\
\hline 15 & Guadix & 1 & ¿C? & Siglos VI / V & Puerta et al. 2004 & Sí & Raya et al. 2003 \\
\hline 16 & El Murtal & 1 & A & $\begin{array}{l}\text { Fin s. VII / } \\
\text { inicios VI }\end{array}$ & Lomba y Cano 2004 & - & - \\
\hline 17 & Lorca & $<4$ & A & Siglos VII/ III & Martínez Alcalde 2004 & Sí & Martínez y Ponce 2002 \\
\hline 18 & Castellar de Librilla & varios & ¿A? & Siglo VI & Ros Sala 1989 & Sí & Ros Sala 1989 \\
\hline 19 & San Pascual, Jumilla & Indet. & ¿C? & ¿? & García Blánquez 1995 & - & - \\
\hline 20 & Los Caños (Zafra) & Indet. & $\mathrm{C} 3$ & Fin siglo V & Rodríguez et al. 2006 & Sí & Rodríguez et al. 2006 \\
\hline 21 & Riera de Sant Simó & 3 & $\mathrm{C} 1$ & Siglo IV & Pons Mellado 1983 & Sí & Pons Mellado 1983 \\
\hline 22 & Darró & 1 & $\mathrm{C} 1$ & Siglos IV/ III & López et al. 1992 & Sí & López et al. 1992 \\
\hline 23 & Turó de Can Joan Capella & 1 & $\mathrm{C} 1$ & Siglos IV/ III & Sánchez et al. 1995 & - & - \\
\hline 24 & Pajar de Artillo (Itálica) & 3 & $\mathrm{C} 3$ & Siglos IV/ II & Luzón 1973 & Sí & Luzón 1973 \\
\hline 25 & Arroyo Hondo & Indet. & ¿C? & ¿Siglos IV/ II? & Recio Ruiz 2002 & Sí & Recio Ruiz 1983 \\
\hline 26 & Illeta dels Banyets & Indet. & ¿C1? & Siglos IV/ III & López Seguí 1997 & Sí & López Seguí 1997 \\
\hline 27 & Tossal de les Basses & 16 & $\mathrm{C} 1$ & Siglos V/ IV & Rosser y Pérez 2004 & Sí & Rosser y Fuentes 2007 \\
\hline 28 & La Alcudia de Elche & Indet. & $\mathrm{C} 1$ & Siglos IV/ II & López Seguí 1995 & Sí & López Seguí 1995 \\
\hline 29 & Sant Miquel de Llíria & 9 & $\mathrm{C} 1$ & Siglos IV/ II & Bonet Rosado 1995 & - & - \\
\hline 30 & El Amarejo & 1 & $\mathrm{C} 2$ & Siglo III & $\begin{array}{c}\text { Broncano Rodríguez } \\
1989\end{array}$ & - & - \\
\hline 31 & Los Villares de Caudete & 1 & $\mathrm{C} 1$ & Siglo III & Mata Parreño 1991 & - & - \\
\hline 32 & La Maralaga & 1 & ¿C1? & Siglos II/I & Lozano Pérez 2006 & Sí & Lozano Pérez 2006 \\
\hline
\end{tabular}


simples, basado en una estructura de sección triangular y eje rectilíneo que define estrictamente un prisma triangular. Las dimensiones máximas de estos prismas se situarían en torno a 11-12 por 7-8 $\mathrm{cm}$, mientras que el formato más pequeño se situaría en torno a 6-7 $\mathrm{cm}$ de longitud y una anchura de 4-5 cm, siendo las combinaciones casi infinitas dentro de estos límites.

TIPO B: Este grupo resulta por el momento excepcional, al haberse documentado únicamente en el yacimiento tartésico-turdetano de Torrevieja (Villamartín, Cádiz) (Gutiérrez et al. 2012). Se trata de piezas también de sección triangular (próxima al triángulo equilátero), pero con un eje de tendencia al cuarto de círculo que rompe la estructura básica prismática, siendo probablemente un derivado directamente del prototipo inicial del Tipo A. Las características son del mismo modo equivalentes al modelo precedente.

TIPO C: Este grupo comprende los ejemplares más evolucionados, propios sobre todo de la fase tardoclásica y helenística, desarrollados probablemente a partir del esquema configurado por el Tipo B o bien directamente del Tipo A, sin descartar su génesis a partir de una influencia griega sobre los prismas fenicios o directamente una introducción tardía por otras vías. Esta familia integra un total de tres variantes o subtipos que han sido diferenciados sobre todo en función de variaciones en la sección -triangular (subtipo C1), cuadrada (subtipo C2) o amorfa (subtipo C3)- siendo, sin embargo, nota común un gran desarrollo del eje curvado hasta alcanzar $1 / 3$ de círculo (o a veces semicircular) en forma de medialuna. Es asimismo destacable el aumento general del volumen total de estos soportes respecto a sus posibles predecesores, incrementando su longitud y desarrollando habitualmente secciones más anchas, especialmente en las superficies inferiores, que habrían servido de apoyo a estos soportes.

Como puede apreciarse, se trata de una tipología muy sencilla, adaptada a la escasa variabilidad formal de los prismas conocidos hasta el momento, la cual hemos creído oportuno simplificar mediante la división en estos grandes grupos o familias tipológicas, sin crear una enorme maraña de sub-tipos y variantes en base a pequeños cambios sobre los esquemas básicos de cada grupo. En nuestra opinión, esto podría haber creado una engañosa percepción de gran variabilidad formal que, en realidad, parece responder, más bien, a una factura general poco cuidada y estandarizada, hecha normalmente a mano, y al propio desgaste de muchas de las piezas analizadas, fruto de cocciones reiteradas y fracturaciones parciales vinculadas a su funcionalidad. Desafortunadamente, en la actualidad no contamos con ningún asentamiento cuya secuencia permita analizar el proceso de evolución formal de los prismas de manera integral, por lo que la información es muy fragmentaria y parcial y solo posibilita una aproximación necesariamente provisional a dicho proceso de uso de los soportes prismáticos.

\section{CONTACTO CULTURALY TRANSFERENCIA TECNOLÓGICA: ORIGEN Y DISTRIBUCIÓN}

Las motivaciones y vías de difusión de este elemento tecnológico parecen indisolublemente ligadas a la propia transmisión al ámbito colonial y posteriormente a las sociedades autóctonas del torno de alfarero y los hornos cerámicos complejos (de doble cámara), así como técnicas de tratamiento de las arcillas y decoración traídas desde el oriente mediterráneo. Su presencia es muy frecuente en alfarerías arcaicas del litoral de Málaga (Montilla, Cerro del Villar, Málaga, Chorreras, La Pancha) (Schubart 1987, Barceló et al. 1995, Arancibia y Escalante 2006, Martín et al. 2006) (fig. 1), lo que resulta tremendamente significativo sobre quiénes pudieron ser los agentes dinamizadores de esta introducción en territorio peninsular y de su difusión a las tierras del interior. Asimismo, destaca a este respecto su total ausencia por el momento en focos alfareros de gran importancia como la bahía de Cádiz, ámbito en el que, a pesar del gran número de alfares excavados, no se localizan prismas ni antiguos ni evolucionados, delimitando una tradición alfarera aparentemente diferenciada.

\section{LA INTRODUCCIÓN DE LOS PRISMAS EN SUELO PENINSULAR ¿INNOVACIÓN FENICIA?}

La tecnología alfarera había alcanzado ya en el II milenio antes de la Era en Próximo Oriente un enorme desarrollo, con la proliferación no sólo de tipos evolucionados de hornos de doble cámara que optimizaban la ecuación combustible-control de las temperaturas, sino también con la configuración de grandes centros de producción excedentarios dotados de múltiples oficinas y áreas de taller especializadas. Las ciudades 
Tabla 2. Propuesta tipológica de los prismas cerámicos usados en los alfares peninsulares. (*) Las localizaciones en cursiva cuentan con evidencias directas (hornos, talleres, vertederos) relacionadas con la producción cerámica en conexión con los prismas.

\begin{tabular}{|c|c|c|c|c|}
\hline & & TIPOLOGÍA & ATESTACIONES* & CRONOLOGÍA \\
\hline $\mathbf{A}$ & & & $\begin{array}{l}\text { Chorreras, Ategua, La Pancha, } \\
\text { Cerro del Villar, El Murtal, Canto } \\
\text { Tortoso, Huelva (P9), Montilla, } \\
\text { Cerro de los Infantes, Torrevieja, } \\
\text { Tejada, Acinipo, etc. }\end{array}$ & $\begin{array}{l}\text { Época arcaica, con mayor fre- } \\
\text { cuencia en los siglos VIII / VII, } \\
\text { aunque también VI a.n.e. }\end{array}$ \\
\hline B & & & Torrevieja (Villamartín) & $\begin{array}{l}\text { ¿Modelo de transición entre los ti- } \\
\text { pos A y C? Variante propia de los } \\
\text { siglos VII y esencialmente el VI } \\
\text { ¿y V a.n.e.? }\end{array}$ \\
\hline & 1 & & $\begin{array}{l}\text { Edeta, Darró, Riera de Sant Simó, } \\
\text { Turó de can Joan Capella, Pajar } \\
\text { de Artillo (Itálica) }\end{array}$ & $\begin{array}{l}\text { Con diversas varíantes regionales, } \\
\text { entre los siglos IV a II, ¿o incluso } \\
\text { hasta el I a.n.e.? }\end{array}$ \\
\hline $\mathbf{C}$ & 2 & & El Amarejo (Bonete, Albacete) & siglo III a.n.e. \\
\hline & 3 & & Los Caños (Zafra, Badajoz) & c. 400 a.n.e. \\
\hline
\end{tabular}

fenicias no fueron en absoluto ajenas a este proceso, clave para centros comerciales redistribuidores necesitados de producciones de vajilla para el intercambio y de ánforas para contener los diversos productos transportados fundamentalmente por vía marítima, siendo buen ejemplo de ello los diversos talleres alfareros documentados en la ciudad de Sarepta (Pritchard 1975: 71-84, Anderson 1987: 41-66). En los albores del I milenio antes de nuestra Era, el proceso de asentamiento fenicio en el occidente mediterráneo conllevó la llegada a las costas peninsulares de esta tecnología desarrollada, que comprendía no sólo el torno alfarero o los hornos bicamerales (bilobulados o de tipo omega) sino también de los complejos procesos de especialización de los artesanos y el concepto de la producción masiva excedentaria y vinculada a funciones comerciales de envergadura extra-regional. Por el momento, las investigaciones arqueológicas en los asentamientos coloniales fenicios de la mitad sur peninsular han deparado parcos resultados en relación con estos primeros pasos de la industria alfarera fenicia-occidental, destacando en este sentido los hallazgos del yacimiento de Cerro del Villar, único enclave costero que ha revelado hasta el momento la existencia de una potente secuencia de hornos alfareros de los siglos VIII a V a.n.e. (Aubet et al. 1999).

El protagonismo de los centros fenicios de la costa mediterránea andaluza se hace evidente en la concurrencia de este tipo de accesorios alfareros en un buen número de esos establecimientos que en la fase arcaica 
tuvieron carácter autosuficiente en relación a la fabricación de los envases para la comercialización de sus producciones agropecuarias. Entre ellos, el ejemplo más notable y mejor documentado es el Cerro del Villar, una isla en la antigua desembocadura del Guadalhorce (Aubet et al. 1999: 334) donde está documentada la producción alfarera durante toda la época arcaica ya que se han citado evidencias desde el s. VIII a.n.e. (Delgado 2011: 16). No obstante, el registro más completo publicado corresponde a principios del s. VI a.n.e., el denominado por los excavadores sector $3 / 4$. Se trata de un complejo industrial constituido por varios hornos, de los cuales sólo dos fueron parcialmente documentados, junto a un ámbito arquitectónico con dos estancias dedicadas a las actividades previas al horneado y quizá como depósito del material acabado (Barceló et al. 1995: 147-183). El taller funcionó a gran escala con una producción en masa de ánforas y, en menor medida, de otras categorías vasculares, en la que los prismas cerámicos tuvieron un empleo destacado, habiéndose documentado cerca de un centenar y medio de ejemplares -Tipo A- sólo en este área (Aubet et al. 1999: 186).

En el núcleo del asentamiento colonial de Malaka se ha venido a sumar en los últimos años la constatación de un horno de cocción cerámica no muy bien definido morfológicamente pero en el cual se ha citado la presencia de un número indeterminado de prismas triangulares depositados en la base de la estructura entre una matriz sedimentaria de cenizas (Arancibia y Escalante 2006: 345, lám. VI). La datación propuesta por sus excavadoras de finales del VII a.n.e. al primer tercio del VI a.n.e. (Arancibia y Escalante 2010: 36403641), viene a confirmar el carácter auto-productor de este núcleo fenicio, para el que se disponía de evidencia más reciente en el área del Teatro Romano, poniendo de manifiesto durante el periodo una trayectoria paralela con el vecino Cerro del Villar.

También en los últimos años han acaecido novedades respecto al sector malacitano de la desembocadura de los ríos de Vélez y Algarrobo, donde se sitúan núcleos coloniales tan importantes como Morro de Mezquitilla, Chorreras y Toscanos. Un área clave entre otros muchos aspectos para explicar la expansión y amplia distribución comercial de los productos alfareros de este origen a lo largo del Occidente y del Mediterráneo Central, que comienza ahora a disponer del soporte empírico de sus barrios industriales e instalaciones alfareras. El yacimiento de Chorreras ha conocido nuevas intervenciones que han permitido definir una extensión de 6 ha más allá de las inicialmente supuestas para este asentamiento urbano (Martín et al. 2005: 11). Fruto de estos trabajos es la delimitación de un sector alfarero situado en una vaguada apartada del núcleo más residencial, ampliando las funciones de este núcleo a la faceta elaboradora de envases cerámicos. En este lugar se ha detectado en superficie la existencia de fragmentos procedentes de hornadas defectuosas y un ejemplar de prisma de arcilla de Tipo A, con sección de triángulo isósceles y módulo más largo de lo habitual en esta clase (Martín et al. 2006: 259-261). Recientemente, actuaciones de arqueología preventiva desarrolladas en el área industrial distinguida han documentado una estructura de horno bilobulado, como parece apreciarse en la información gráfica, sin que en el informe preliminar los autores lleguen a concretar su empleo alfarero (Ruescas y Ramírez 2010: lám. VII-XIII).

El yacimiento de La Pancha (Vélez-Málaga) se ha descrito como un gran centro industrial, situado al borde de la costa, en la margen derecha de la desembocadura del Algarrobo y a corta distancia de Morro de Mezquitilla que se ubica en la otra ribera. La excavación se realizó cuando el lugar había sido parcialmente destruido, aunque los restos descubiertos ponen de manifiesto la envergadura del establecimiento (Martín et al. 2005: 14-15). Las estructuras fornáceas no han sido localizadas pero la documentación de un testar y diversos ámbitos edilicios, donde se almacenaron por separado los envases de transporte de las demás categorías -como productos barnizados y pintados-, junto a una calle pavimentada con espacios bajo cubierta sostenida por postes, recuerdan el urbanismo de las áreas de producción y mercado de Cerro del Villar. Asimismo, se ha citado un número indeterminado de prismas como elementos auxiliares en la carga de los hornos que portan manchas negruzcas, como efectos de la cocción, y otros elementos del proceso de fabricación como machacadores para la preparación de los desgrasantes o alisadores para el modelado (Martín et al. 2006: 263-265). En base al contexto cerámico se ha propuesto una datación de la segunda mitad del s. VII a.n.e. y el primer cuarto del VI a.n.e. (Martín et al. 2006: 276). La posición geográfica relativa a la costa, los valles fluviales y los asentamientos coloniales de los ríos Vélez y Algarrobo, junto a las características de este taller, dan cumplida idea de la magnitud productiva y la proyección comercial del sitio.

Hacia occidente y en la antigua ensenada del río Guadiaro se ubica el yacimiento de Montilla, ya en un punto próximo al Estrecho de Gibraltar, las antiguas Columnas de Melqart. De este lugar procede la primera referencia al registro de prismas triangulares relacionados, todavía entonces de forma insegura, con 


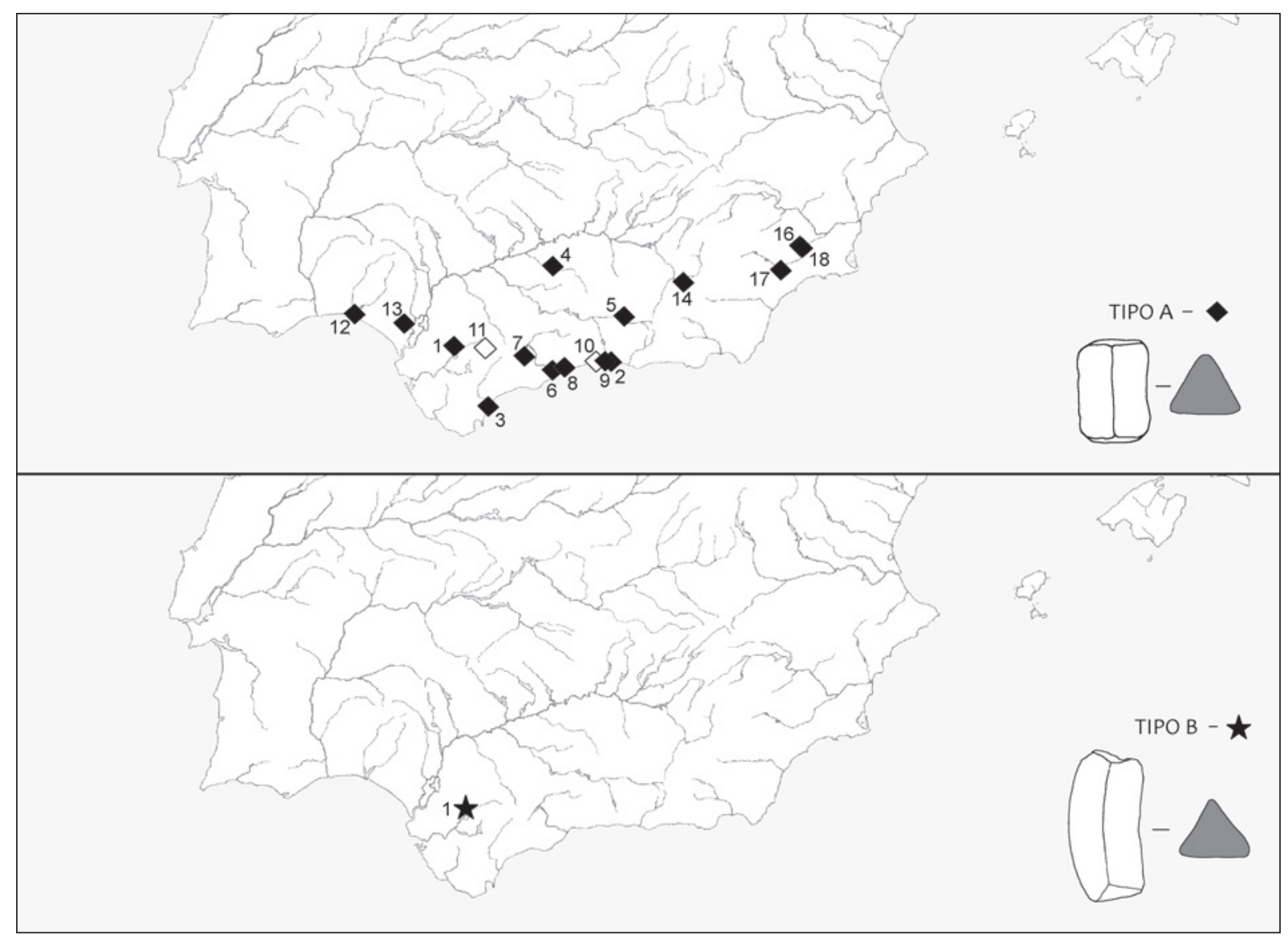

Figura 1. Plano de dispersión de los prismas de los Tipos A y B en la mitad sur de Iberia.

los procesos alfareros proponiendo entre otras hipótesis su participación como soportes en la carga de hornos (Schubart 1987: 206). Se describieron nueve prismas cerámicos del Tipo A, figurando un total de once ejemplares entre individuos completos y fragmentados (Schubart 1987: fig. 7), mostrando como característica general rastros de los procesos de combustión continuada en sus superficies. El yacimiento ha tenido cierta controversia en cuanto a su atribución fenicia, debido a la presencia de un primer nivel integrado únicamente por cerámicas a mano. El propio excavador ofrecía entre los modelos explicativos por él manejados, la posibilidad de un asentamiento fenicio próximo al yacimiento autóctono excavado, que sería el responsable de la fuerte influencia cultural observada en los siguientes niveles de ocupación (Schubart 1987: 208-209). Este patrón podría atender a la implantación de una oficina alfarera fenicia datada entre finales del s. VIII a.n.e. e inicios del VII a.n.e., a la que se asociaría el empleo de los prismas de Montilla, alejada del núcleo residencial pero en el espacio ocupado previamente por el asentamiento de la población residente.

\section{LA DIFUSIÓN DE LOS PRISMAS AL ÁMBITO INDÍGENA MERIDIONAL IBÉRICO}

Como sugerimos en el apartado anterior, el origen peninsular y primera utilización de estos prismas parece poder situarse con relativa precisión en los asentamientos coloniales fenicios de la costa mediterránea andaluza durante los siglos VIII a.n.e. y VII a.n.e., con especial incidencia de los hallazgos conocidos hasta el momento en el entorno malacitano, en la franja entre el estuario del Guadiaro, la propia Malaka y el sector costero Vélez-Algarrobo. La falta de evidencias no permite por ahora dilucidar si esta área matriz podría 
haberse extendido más al Este, englobando otros centros fenicios principales como Seks, Abdera o incluso Baria, núcleos en los que, por el momento, no consta la documentación de prismas ni de restos de talleres alfareros pero en los que parece razonable que existiese este tipo de autoproducción, ya vislumbrada en el caso bariense (López et al. 2011: 55-56 y 154).

La transferencia tecnológica de la que formaban parte los prismas se extendió muy rápidamente en los medios productivos indígenas del mediodía peninsular, al abrigo de las relaciones de todo tipo que la organización colonial debió desarrollar en los territorios bajo control de la población autóctona. Así, en un plazo de tiempo relativamente corto que se fijaría en diferentes momentos del s. VII a.n.e., la innovación tecnológica alfarera introducida por estos elementos intermediarios se detecta dispersa por un notable conjunto de lugares, en algún caso distantes del núcleo fenicio originario de la costa mediterránea (fig. 1).

Los valles del Guadalhorce y del Guadalteba se han revelado como parte del entramado fundamental de vías naturales de comunicación entre el litoral mediterráneo, las depresiones interiores del Surco Intrabético, el valle del Guadalquivir y las tierras atlánticas, que con el trasfondo de las referencias de la Antigüedad al camino alternativo a Tartessos, han encontrado un refrendo en una rica casuística arqueológica (Aguayo et al. 1995: 87-90). Un ejemplo de la temprana presencia de los prismas en el interior del Guadalteba es el caso de las Huertas de Peñarrubia, un pequeño asentamiento de carácter agropecuario en misma vega aluvial (García 1999: 363-372). En este enclave compuesto por ámbitos de planta oval y otros de muros rectos, se han recogido al menos cuatro ejemplares completos de prismas de lados rectilíneos que se pueden datar en el s. VII a.n.e., sin que se disponga de más datos sobre una posible vocación alfarera dado el carácter preliminar de los trabajos (García 1995: 100-102, García et al. 1995: 34). En la misma región, se podría asignar una cronología del s. VIII a.n.e. a un ejemplar dudoso procedente del yacimiento fortificado de los Castillejos de Teba. El objeto fracturado que fue recuperado en uno de los niveles basales de la estratigrafía, en un contexto de cerámicas a mano, presenta una decoración incisa por las caras conservadas que lo aleja del carácter casi industrial de los objetos tratados, habiéndose relacionado con una posible funcionalidad simbólica (García 1995: 114 fig. 36), para la cual se podrían aducir otros ejemplos como se verá abajo.

La depresión interior de Ronda se configura como un área privilegiada entre la costa malagueña, el valle del Guadalete a Occidente, y el del Guadalquivir al Norte, con vía directa de comunicación a la costa mediterránea a través del río Guadiaro. La presencia de prismas en Acinipo (Ronda, Málaga) es conocida actualmente sólo a través de referencias indirectas (González et al. 1995: 163), sin que por el momento dispongamos de una publicación monográfica amplia sobre las áreas artesanales de época orientalizante y turdetana localizadas al parecer tanto en Acinipo como más notoriamente en el propio casco urbano de la actual Ronda (Aguayo et al. 1992: 340), caracterizadas por la aparición de varios hornos alfareros y algunas dependencias anexas que parecen caracterizar la producción cerámica en la zona desde época tartésica hasta al menos el s. IV a.n.e. (Aguayo y Carrilero 1996, Castaño 2005: 23-28). La temprana implicación de los prismas en los procesos alfareros autóctonos, que podría datarse también en Torrevieja, ya en la cuenca media del río Guadalete, durante el s. VII a.n.e. si no antes, encuentra su refrendo sincrónico más distante en varios ejemplos de tipo clásico (A) documentados en Ategua, en plena campiña cordobesa del río Guadajoz, al sur del Guadalquivir. Estos prismas proceden de diversos contextos de la Fase II y III del yacimiento cordobés, en los que se encuentra un repertorio vascular a torno plenamente orientalizante (López 2008: 240-241 y 258-259). A pesar de no contar con otras evidencias alfareras, los análisis físico-químicos de las pastas cerámicas no parecen contradecir una producción local (López 2008: 262-264).

El yacimiento de Torrevieja (Villamartín, Cádiz) ha sido objeto de trabajos arqueológicos intermitentes entre 1998-2009. Se trata de un importante enclave en la cuenca media del río Guadalete, con una extensión original entre $6 / 8$ ha -situado en una geoestratégica encrucijada de vías de comunicación terrestres y fluviales a medio camino entre la serranía de Ronda y la bahía y campiñas gaditanas-, que cuenta con una intensa ocupación desde los siglos IX a.n.e. a mediados del IV a.n.e. Se ha intervenido arqueológicamente en diversos contextos de esta fase, entre otros, sobre un área de producción alfarera del Bronce Final (Gutiérrez y Jiménez 2010: 420), demostrando la honda tradición que esta actividad tuvo en el asentamiento; diversas áreas de almacenamiento, fundamentalmente de tipo subterráneo pero también de almacén elevado; fondos de cabaña pertenecientes al Bronce Final y la fase Orientalizante, junto a otros ámbitos habitacionales con paramentos rectos y un carácter más orgánico para la etapa tardoarcaica y turdetana; así como el foso de la trama defensiva del oppidum (Gutiérrez y Reinoso 2003: 212-213). 
Del mismo modo, se han puesto al descubierto parcialmente dos edificios singulares, uno de ellos de gran tamaño y planta cuadrangular con aparejo de mampostería y grandes sillares de refuerzo, con alzados de adobe. En todos los puntos sondeados se confirma un cierre del asentamiento caracterizado por una coyuntura de abandono datada a mediados del s. IV a.n.e.

Los nueve prismas de Torrevieja han sido registrados en diferentes contextos y posiciones (Gutiérrez et al. 2012, para los detalles contextuales y la bibliografía generada). Cinco ejemplares del Tipo A y fragmentos indeterminados proceden de los rellenos que amortizaban los pavimentos más antiguos del gran edificio singular excavado en 2009, que debió ser levantado a lo largo del s. VII a.n.e.; al exterior del mismo se identificó uno más del Tipo B. Otro del tipo A fue recogido entre los niveles basales del foso cuando este aún se conservaba abierto y en funcionamiento, acompañado por materiales caracterizados por cerámicas grises y a mano tartésicas, previos a su cegamiento a mediados del s. IV a.n.e. Los dos últimos ejemplares del Tipo B proceden de la Estructura 510, una gran fosa que había amortizado pequeñas estructuras de almacenamiento del Bronce Final, con un relleno compuesto por vertidos de fauna, cerámicas y algunos metales que, por el complejo vascular de cerámicas pintadas, barniz rojo, grises, comunes y a mano, debe datarse a principios del s. VI a.n.e. (Reinoso y Gutiérrez 2006: 117). Hasta el momento no han sido localizadas estructuras fornáceas ni testares, pero diferentes ejemplares con cocciones fallidas y las primeras analíticas físico-químicas podrían apuntar en el sentido de una actividad alfarera local.

Teniendo en cuenta las premisas de un uso temprano en los medios indígenas, tanto el pequeño conjunto del alfar de Los Algarrobeños (Martín et al. 2005: 22 y 2006: 278) como el ejemplar de prisma documentado en el área del teatro romano de la antigua Malaka, parecen testimoniar la continuidad en el uso de estos elementos, aún en los albores de la etapa púnica, en consonancia con la perduración vislumbrada en el horno más reciente del cercano Cerro del Villar (Aubet et al. 1999). El citado prisma malagueño parece indicar la continuidad de alfares activos durante el siglo VI a.n.e. o los inicios del $\mathrm{V}$ a.n.e. en el entorno próximo, en una etapa coetánea a las fases de producción más recientes de la última fase alfarera de Cerro del Villar. La pieza responde al tipo "clásico", con escaso desarrollo longitudinal, superficies cuidadas y sección triangular con las aristas levemente redondeadas, documentándose asociado a un par de fragmentos cerámicos amorfos, que el autor describe como posibles separadores o soportes auxiliares de las tareas de cocción, señalando el más que probable uso alfarero de los hallazgos descritos. Esta hipótesis vendría avalada por la presencia de desechos de cocción adscritos a las fases más recientes de ocupación de la colina de la Alcazaba de Málaga (Gran 1991: 80, nota 147, fig. 54, nº 12-14). Asimismo, la presencia en los niveles fenicio-púnicos de numerosos fragmentos de placas de adobes con improntas vegetales podría reforzar la idea de la existencia de alguna estructura de cocción en las inmediaciones, respondiendo estas placas con bastante fidelidad a los adobes plano-convexos usualmente utilizados por los artesanos gadiritas en la larga nómina de estructuras alfareras conocidas en sus talleres (Sáez et al. 2005: 482-489).

A tenor de las cronologías más antiguas detectadas por el momento y a la demostrada perduración de su utilización hasta al menos la primera mitad del siglo $\mathrm{V}$, en contraste con los datos proporcionados por Gadir, consideramos que estos elementos tecnológicos fueron difundidos especialmente desde este núcleo malagueño hacia otros asentamientos costeros y hacia el interior, en unión indisoluble con otros avances, como el torno o los hornos bicamerales. La proximidad de grandes centros tartésicos como Acinipo y la actual Ronda, con contactos tempranos con el mundo fenicio costero y grandes posibilidades alfareras locales (Aguayo 2001: 77-81), pudo ser una de las vías principales de penetración hacia el mundo indígena del Bajo Guadalquivir y, en general, hacia el Oeste andaluz. De cualquier forma, es evidente que hacia los inicios del s. VI a.n.e. la utilización de los prismas alfareros fenicios se había extendido al occidente andaluz, pues además de los nueve ejemplares documentados en Torrevieja, contamos con un pequeño grupo de hallazgos onubenses que parecen sugerir una difusión quizá combinada por vía marítima e interior, probablemente a través de núcleos como Spal, Cerro Macareno o Carmona. En este contexto, no debemos olvidar los ejemplares dudosos, como el fragmento cubierto de pigmento rojo recuperado en El Carambolo (Belén y Escacena 1999: 113, fig. 10, 1) o el atípico de mármol procedente de Casa Saltillo en Carmona (Belén et al. 1997: 110, fig. 28, 4) que, aún dentro de contextos sacros, quizá pudiesen estar evidenciando estos procesos de uso de prismas con una funcionalidad indeterminada.

En concreto, los indicios disponibles son los referidos a la presencia de prismas de tipo lineal y sección triangular (Tipo A) en el casco urbano de Huelva y en el asentamiento de Tejada la Vieja (Escacena del Campo, Huelva). El prisma localizado en el casco urbano de Huelva procede de la actuación arqueológica realizada 
en el solar de c/ Puerto 9, en la ladera del antiguo Cabezo del Molino de Viento, en el cual se llevó a cabo un amplio sondeo a fin de conocer la secuencia estratigráfica de la zona. El ejemplar estudiado -descrito como "ladrillo"- y relacionado con las toberas presentes en el mismo contexto (Fernández 1989: 158-159) fue documentado en el nivel IIb (estrato 9a), no asociado a estructuras edilicias, en el que destacaba la gran cantidad de material recuperado, en especial el notable conjunto de cerámicas griegas, que permiten un gran ajuste de la cronología del depósito, situada entre c. 590-560 en el Tartésico Final II (Fernández 1989: 237-253).

Por su parte, el ejemplar de Tejada la Vieja procede del corte B-5/87, en concreto de la excavación del lienzo de muralla afectado por las excavaciones de A. Blanco y también de la cara oriental del contrafuerte anexo, documentándose el prisma en un nivel ceniciento junto a restos óseos y cerámicos a mano y torno (Fernández 1987: 101). Precisamente, el material asociado (Fernández 1987: lám. XXI-XXIV) nos aporta los indicios de datación más interesantes, estando representados diversos tipos de cazuelas a mano, pithoi, jarras, carretes, cuencos y numerosas ánforas (destacan dos T-11.2.1.0), que parecen apuntar a una cronología temprana dentro de la fase III del poblado, probablemente en momentos avanzados del s. VI a.n.e. o inicios del $\mathrm{V}$ a.n.e., sin que podamos descartar un posible carácter residual del prisma en un nivel más moderno que su fase de uso-fabricación.

La difusión del uso de los prismas alfareros en la zona oriental andaluza fue aún más precoz, como demuestran los ejemplares atestiguados en Cerro de los Infantes (Mendoza et al. 1981: 193-194 fig. 18 k) o Canto Tortoso (González et al. 1995: 163-164, fig. 12, 6-7), ambos en Granada, en contextos de momentos avanzados del s. VII a.n.e. o primera mitad del VI a.n.e., fenómeno en el que, dadas las vías naturales de comunicación, pudieron proceder de posibles alfarerías fenicias localizadas en los principales núcleos del área (Seks, Abdera, Baria, etc.). Además, en esta zona contamos con la asociación más antigua en ámbito indígena de los propios prismas con hornos alfareros, como el exhumado en Cerro de los Infantes, de planta oval con corredor de acceso y pilar central de adobe diferenciado de la pared, lo que parece indicar la transmisión en un solo paquete de estos avances tecnológicos aplicados a la producción cerámica masiva (Contreras et al. 1983: 533-534). En ambos casos las tipologías de los prismas responden al modelo "clásico" (Tipo A), con líneas rectas suavizadas y secciones triangulares, similares morfométricamente a los usados coetáneamente por los artesanos fenicios costeros en el taller de Cero del Villar.

El uso de prismas alfareros de este tipo fue rápidamente acogido por las comunidades indígenas asentadas en territorio de la actual Murcia, también en momentos tempranos, que podemos ubicar entorno a las postrimerías del s. VII a.n.e. o los inicios del VI a.n.e., como sugieren los testimonios recuperados en los yacimientos de Cabezo de la Fuente de El Murtal (Lomba y Cano 2004: 194-196), Castellar de Librilla (Ros 1989: 295-297) o en los talleres alfareros de Lorca (Martínez 2006: 242-243), ubicados en la ribera del río Guadalentín. Las vías de difusión hacia el Este de los prismas, hasta alcanzar esta nueva área, parecen por el momento más complejas de delimitar espacial y cronológicamente, sin que podamos descartar una penetración por vía marítima o un contacto a través de vías terrestres; si bien, la frecuentación del fondeadero de Mazarrón desde época arcaica por buques mercantes fenicios y la cercanía de éste a la propia Lorca nos llevan a pensar en esta vía como la más factible.

En resumen, el mapa de dispersión de los prismas para esta fase, que comprendería grosso modo desde fines del s. VII hasta el V a.n.e. muestra con relativa claridad - pese a la escasez cuantitativa del registro- varias cuestiones (fig. 1):

- Por un lado, la continuidad de la vigencia en todos los ámbitos geográficos del modelo tradicional de líneas rectas y secciones triangulares uniformes.

- Por otro, la rápida expansión de estos elementos tecnológicos tanto al Este como al Oeste del área de Málaga, probablemente tanto por vía marítima como a través de rutas interiores y valles fluviales, alcanzando grandes centros indígenas que ya en esta etapa temprana debieron dotarse de talleres cerámicos volcados a la producción excedentaria con fines comerciales. En este sentido, parece razonable plantearse el destino de dicha producción, que a nuestro parecer no se limitaría al intercambio agropecuario con los agentes fenicios costeros, sino que probablemente daría origen o impulsaría las redes de comercio netamente indígenas.

- Por último, parece también evidente a tenor de las evidencias disponibles que este uso de los prismas se limitó en esta fase de consolidación a la zona sur peninsular, la más semitizada, tanto en ámbito costero como interior, no existiendo evidencias de una transmisión tecnológica más allá de la región murciana por el Este ni apenas al Norte del valle del Guadalquivir, cuestión que quizá pueda estar evidenciando las áreas de mayor interés o actividad de 
los fenicios en el interior ibérico durante estas centurias, si bien no debemos perder de vista la evidencia emergente para las postrimerías de la fase del área meridional portuguesa y extremeña (Alonso et al. 2006: 93-97).

- La utilización con fines alfareros de estas piezas parece, al igual que en la fase anterior, fuera de duda, a pesar de que varios ejemplares carecen de un contexto asociado directamente a tales actividades, especialmente los casos onubenses.

\section{LA EVOLUCIÓN MORFOLÓGICA DE LOS PRISMAS EN MOMENTOS TARDÍOS}

La utilización de estos soportes o elementos auxiliares de los procesos artesanales de la alfarería no finalizó con los alfares de plena época ibero-turdetana, según parecen indicar algunos indicios arqueológicos, sino que se adaptó a las nuevas corrientes tecnológicas que se imponían tanto en el mundo costero como en el interior ibérico. La tradicional morfología de líneas rectas, sección triangular tendente a triángulo equilátero y aristas marcadas pero demasiado angulosas, debió dar paso paulatinamente en las áreas de mayor uso de estos elementos a nuevos prototipos evolucionados, de similar funcionalidad (apoyo y separación de las piezas en procesos de secado y/o cocción) pero con modelos más estilizados. Éstos se caracterizan por la mayor longitud de los ejemplares, la tendencia a la forma semicircular, un cierto aplanamiento, probablemente relacionado con una mayor estabilidad y la existencia de mayor diversidad morfológica en las secciones, que parecen variar desde ejemplares triangulares, muy apegados a los prototipos de fases precedentes, hasta piezas ovaladas no aristadas pero que se inspiran en el esquema funcional anterior. Este proceso de transición, así como la eclosión de las piezas morfológicamente evolucionadas, son prácticamente desconocidos, al existir por el momento escasos contextos alfareros del litoral o interior que puedan datarse en esta fase de conversión. En este sentido, no podemos descartar que dicha transformación fuese originada por algún centro costero del área mediterránea andaluza, zona probable de origen de la tecnología de los prismas alfareros, o igualmente tuvieran un origen en centros ibero-turdetanos; si bien en cualquier caso la innovación habría tenido lugar en algún momento avanzado del s. V a.n.e. o en la primera mitad del IV a.n.e., como parecen sugerir los indicios del alfar malagueño de Arroyo Hondo (Recio 1983: 172, 2002: 50-70) o los hornos extremeños de similar datación del asentamiento rural de Los Caños (Alonso et al. 2006: 83-84). La morfología de algunos de los prismas de Torrevieja (Villamartín) también parece sugerir una gestación temprana de estas morfologías curvadas en el Sur peninsular pues, aunque en general responden con bastante fidelidad al modelo clásico, tres de los ejemplares documentados presentan ya leves indicios de curvatura (el definido como Tipo B). La publicación monográfica de áreas alfareras de época ibérica como las localizadas en Marmolejo (Molinos et al. 1990: 197-203), Ronda (Aguayo y Carrilero 1996) o Guadix (Raya et al. 2003, Puerta et al. 2004: 448449), así como el análisis más amplio de los materiales de otras ya conocidas como el alfar malagueño de Aratispi (Perdiguero 1988: 6-7), permitirá en el futuro la contrastación de este posible origen en el cambio formal en los prismas. En el caso del horno de Guadix, sus excavadores citan la presencia en un nivel de cenizas, junto a otros fragmentos de adobes, de uno con "forma de media luna" (Puerta et al. 2004: 448), que quizá pueda corresponder con una forma evolucionada de prisma cerámico.

Dejando a un lado esta cuestión del modo, datación y área generatriz, sí contamos con argumentos sólidos para afirmar una amplia extensión del uso de estas piezas en gran cantidad de alfarerías del área ibero-turdetana, abarcando una extensión mucho mayor que la documentada para los prismas clásicos de las fases arcaicas y tardo-arcaicas. En la propia área andaluza, además de los indicios ya enunciados de Arroyo Hondo (según parece, los más antiguos por el momento), constatamos la utilización de piezas semicirculares en el alfar documentado en el Pajar de Artillo de Italica (Santiponce, Sevilla) (Luzón 1973), en el bajo Guadalquivir, área con gran tradición alfarera desde centurias anteriores. En concreto, los elementos de tecnología alfarera localizados en el Pajar de Artillo se relacionan de forma directa con el horno cerámico localizado en el cuadro C-4, asociado a la denominada segunda fase de ocupación, perteneciendo a un modelo evolucionado muy tardío que parece poder ponerse en relación con los prismas rectilíneos y aristados de la etapa arcaica y tardo-arcaica. Se trata de tres ejemplares en forma de media luna, de sección aparentemente más cercana al óvalo que a las triangulares usuales, de unos 10-12 cm de longitud, realizados a mano de forma tosca y descuidada, cuestión lógica al tratarse de elementos de uso industrial. Se asocian directamente a los niveles de relleno y uso del horno alfarero documentado, proponiendo su excavador un uso vinculado a separar la cerámica dentro del horno y permitir el paso del aire caliente a su 
alrededor (Luzón 1973: 23). Los materiales cerámicos vinculados a los contextos de hallazgo parecen señalar una cronología algo más antigua que la propuesta por Luzón inicialmente para los niveles de uso y amortización del horno (segunda mitad del s. II a.n.e.), y de esa forma se han pronunciado diversos investigadores (Ruiz 1998: 198-199 y 217-218), pudiendo retrotraerse la producción de este alfar al menos hasta el último cuarto del s. III a.n.e. (Chic y García 2004: 308), presentando muchas de las cerámicas de producción local e importadas (Luzón 1973: lám. LI-LXVIII) gran afinidad con las producciones gadiritas de dicho horizonte cronológico (Sáez 2004, 2005, 2008).

Mención aparte merece la presencia de estos prismas semicirculares, ya morfológicamente definidos por completo, en el área extremeña en asociación de nuevo con contextos alfareros. Como señalamos anteriormente, el asentamiento rural de Los Caños (Zafra, Badajoz) ha proporcionado los primeros indicios de la presencia de estos elementos evolucionados en esta área interior fuertemente orientalizada, precisamente en una etapa de gran desarrollo de las actividades agropecuarias y de intercambio en la zona. El área excavada del yacimiento parece mostrar la existencia de un pequeño núcleo agrícola dotado de varias estancias dedicadas a labores de molienda y domésticas, además de dos hornos alfareros de doble cámara y pilar exento, así como una amplia área de cultivo anexa (Rodríguez et al. 2006: 102-106). Los prismas aparecen en buen número repartidos por diversas estancias (números 1-3 y 11), especialmente asociados al denominado Horno 2, en cuyo relleno se localizaron asimismo numerosos restos cerámicos datantes, así como adobes y cenizas, mostrando de nuevo su interrelación directa con usos artesanales alfareros vinculados en buena medida a los procesos de secado, almacenaje y especialmente de cocción. Respecto a la tecnología y funcionalidad de estas piezas sus propios excavadores destacan su manufactura a mano, con un estándar morfométrico (unos $20 \mathrm{~cm}$ de diámetro-longitud) pero con diversidad de secciones, así como el hecho de ser «[...] piezas de carácter utilitario» por lo que proponen que «[...] el hecho de que algunas de ellas aparezcan recocidas y su relativa proximidad a los hornos invitan a considerarlas hipotéticamente como posibles separadores o incluso elementos integrados en la propia estructura de dichos hornos» (Rodríguez et al. 2006: 97). Destaca sobremanera de este yacimiento la localización de un uso temprano de este tipo de prisma evolucionado en una zona situada al interior, si bien con una fuerte trayectoria de interrelación con el mundo tartésico-fenicio situado al sur de Sierra Morena, en un momento sincrónico al actualmente disponible para la aparición de esta innovación en el ámbito costero. La presencia de estos prismas en la zona abre asimismo la posibilidad, por el momento sólo sospechada debido a la escasez de talleres alfareros excavados, que este tipo de elementos fuesen bien conocidos ya por los artesanos del área en fases históricas precedentes, así como el hecho de que su uso se extendiese a un amplio número de talleres, al menos para las fases coetáneas o posteriores a la detectada en Los Caños.

El uso de estos prismas evolucionados está también sólidamente documentado en el área levantina en varias alfarerías de la zona de Murcia, Alicante y Valencia. Así, parece factible pensar en un número de centros mucho mayor de lo que las publicaciones disponibles permiten vislumbrar. En el área murciana contamos con los indicios aportados por las alfarerías ibéricas exhumadas en el casco urbano de Lorca (Martínez y Ponce 2004: 387-388), así como con las piezas halladas en el yacimiento de Pasico de San Pascual (Jumilla), también en la ribera del mismo río (García 1995: 17). Sin embargo, los indicios más numerosos y contundentes provienen de los alfares ibéricos alicantinos, en los que parece ser frecuente el hallazgo de estas piezas (López 2000: 246-248). Como botón de muestra de la vitalidad productiva y comercial de estos centros de la Contestania, hay que señalar su presencia en el taller de Illeta dels Banyets, en donde "[...] tanto en el testar como en los alrededores de los hornos encontramos soportes semilunares de sección triangular que podrían estar relacionados con la disposición de las piezas para la cocción" (López 1997: 244). Asimismo, estos prismas están documentados en buen número y aparentemente con la misma finalidad en los testares del alfar de La Alcudia en Elche (López 1995: 231-234). En el área de la Albufereta alicantina, también se ha individualizado un importante complejo alfarero en el asentamiento de El Chinchorro/Tossal de les Basses (Rosser y Pérez 2004: 185-188). Esa destacada actividad industrial se ha podido comprobar con el registro de abundantes estructuras de vocación alfarera como canteras de extracción de arcillas, pozos de agua, cubetas para decantación, al menos tres hornos y diversos testares, de donde procede un buen conjunto de prismas semilunares datados en el s. IV a.n.e. (Rosser y Fuentes 2007: $53-55$ y 103$)$.

El yacimiento ibérico de El Amarejo (Albacete) se localiza en la transición entre la submeseta sur y el área costera levantina, comunicadas a través del corredor natural de Almansa. Entre los materiales de su conocida 
favissa, anexa a los departamentos 1-3, se recuperó un objeto definido como soporte semilunar con evidencias de la acción directa y continuada del fuego (Broncano 1989: 108 fig. 34), cuya sección cuadrada sirve para constituir nuestro Tipo C2. El depósito votivo estaba integrado por una heterogénea representación de objetos cerámicos, metálicos, líticos, artefactos óseos y de madera, adornos de joyería, fauna terrestre y marina, restos de tejidos y frutos. El conjunto datado a lo largo del s. III a.n.e., ha sido interpretado como testimonio del culto tributado a una deidad femenina (Broncano 1989: 235), como demostrarían el carácter genérico de algunas ofrendas, los askoi ornitomorfos y un pebetero de cabeza femenina. Entre la variedad de hornos con diferentes funcionalidades citados en El Amarejo, a excepción de la propuesta de una producción de terracotas junto al departamento 4 , el resto de estructuras fornáceas se relacionan con la confección de cerveza o la calefacción de las estancias donde aparecen (Alfaro 1995: 233-235). Es llamativo que el único paralelo peninsular documentado por ahora para este prisma del Tipo C2 corresponde a algunos elementos de morfometría muy similar (pero algo más curvados hasta llegar a la mitad de círculo) documentados en Mérida en relación a la posible actividad de un alfar de época altoimperial dedicado a la fabricación de terracotas, paredes finas y otras cerámicas cuidadas (Rodríguez 1996: fig. 1.1-6), lo que parece concordar bien con la tradición de uso de estos prismas curvados en otras áreas mediterráneas (v. infra). Resulta difícil por el momento concretar si estos ejemplares emeritenses son producto de una evolución de la tecnología de sustrato peninsular o fueron introducidos posteriormente en la zona dentro de aportes culturales y tecnológicos romanos.

La cuenca del Turia y la comarca interior de la Plana de Utiel, formaron parte durante la segunda Edad del Hierro de los territorios políticos de dos formaciones sociales ibéricas lideradas por sendas capitalidades. Nos referimos en primer lugar a Tossal de Sant Miquel, la antigua Edeta, en cuyo territorio de producción no se han citado hasta la fecha alfares que hayan registrado la presencia de prismas evolucionados. Sin embargo, en la propia cabecera de la Edetania, en este asentamiento de Llíria puede rastrearse su existencia, figurando entre la clasificación del repertorio ergológico en el Grupo V, constituyendo dentro del Tipo 6 de los Diversos, el Subtipo 2 con la definición de morillo (Bonet 1995: 40). Se han detectado ejemplares del Tipo C1 en diferentes ámbitos, los denominados Departamento 31, 35, 36 (5 ejemplares), 41 y 46, siendo destacable su coexistencia con abundantes recortes cerámicos circulares, especialmente en el Departamento 46 (Bonet 1995: 154-193). En el asentamiento se han descrito diversos hornos con funciones domésticas o previsiblemente metalúrgicas en los Departamentos 42b, 43, 44 y 118 (Bonet 1995: 360-362), sin apuntar ninguna actividad alfarera. Es reseñable destacar cómo, sobre el plano urbano actualizado del sector I del Tossal de Sant Miquel (Bonet 1995: 41 fig. 2B), existe una vinculación espacial de proximidad entre los hornos de los Departamentos 42b-44, con los prismas semilunares de los Departamentos 41 y 46 situados a los extremos del mismo ámbito arquitectónico, o su relación con los prismas de los Departamentos 35 y 36 que se registraron al otro lado de la calle, por lo que cualquiera que haya sido la función de dichos hornos, es notable la correlación de estos instrumentos auxiliares con los mismos.

Por el contrario, en el territorio gestionado desde el yacimiento de Los Villares en Caudete de las Fuentes (Valencia), identificado con la antigua Kelin de las amonedaciones, son conocidos diversos centros de producción alfarera dentro del territorio político dependiente de este oppidum (Duarte et al. 2000: 231-237), entre los que se cuentan los talleres con hornos bicamerales de la Casilla del Cura (Venta del Moro, Valencia), con producción de ánforas para los siglos V/-IV (Martínez et al. 2000: 226-227), Casa Guerra (Requena, Valencia) y especialmente el de La Maralaga (Sinarcas, Valencia) ya datado en los dos últimos siglos a.n.e., donde se ha citado un prisma de eje curvado (Lozano 2006: 141). En la fase Villares IV fechada en el s. III a.n.e., se recogió un prisma fragmentario incluido como morillo en la categoría de los Diversos (Mata 1991: 95 fig. 52-7). Esta constatación abriría la posibilidad de una producción propia en el centro rector, sin detrimento de un patrón de talleres dependientes ya conocidos en su distribución territorial por la investigación (Duarte et al. 2000: 237-238).

Sin embargo, la extensión del uso de los prismas de tipo evolucionado no se detuvo en el área levantina, sino que aparentemente por vez primera alcanzó la franja costera de la Cataluña central, en la actual provincia de Barcelona, estando bien documentada su presencia en al menos tres asentamientos, dos de ellos muy vinculados a la producción cerámica prerromana.

El asentamiento ibérico más meridional de los citados es el costero de Darró (Vilanova i la Geltrú, Barcelona), activo al menos entre los siglos IV y I a.n.e., con gran vitalidad alfarera en todas sus fases urbanas (López et al. 1992: 16-17). Destaca en este sentido, la documentación de una pareja de hornos cerámicos en la zona 0 , correspondientes a la última fase del enclave (siglos II/I a.n.e.), y de hasta tres estructuras más en la 
denominada zona 1 , con una cronología más antigua (quizá entre fines del s. IV a.n.e. y las postrimerías del s. II a.n.e.). Los prismas asociados a esta producción alfarera (López et al. 1992: 37 fig. 29, 20) responden a la ya referida morfología semicircular irregular con sección triangular tendente a triángulo isósceles, manufacturados en pasta beis oxidante. Desconocemos el número y ubicación exacta de estos prismas, si bien parece factible pensar en una relativa abundancia de estas piezas en un asentamiento tan estrechamente vinculado a la producción cerámica. En cualquier caso, este yacimiento parece aportar información adicional sobre la cronología y las vías de difusión de estos elementos alfareros desde el sur peninsular: por un lado, sugiere un inicio temprano del fenómeno, quizá situado en los últimos compases del s. IV a.n.e. o en los inicios del III a.n.e.; por otro, la documentación de al menos un horno dedicado a la fabricación de imitaciones de ánforas púnico-ebusitanas en momentos avanzados del s. III a.n.e., que señala la vocación comercial del asentamiento y quizá la primacía cartaginesa (bárcida) sobre el lugar al menos durante el enfrentamiento contra Roma, presencia exógena que bien podría haber constituido el vehículo idóneo de transmisión desde el Sur peninsular. En cualquier caso, ante la absoluta falta de evidencias para época precedentes, no sólo en tierras catalanas, sino más allá de la región murciana, parece razonable pensar en una introducción tardía ex novo de estos prismas más que en una evolución funcional endógena, si bien por el momento resulta imposible discriminar los cauces y vehículos empleados para ello.

El pequeño asentamiento rural de Turó de Can Joan Capella (Granollers), vinculado a la explotación cerealística masiva y ocupado durante gran parte del s. IV a.n.e. y la primera mitad del III a.n.e., se ubicó en una pequeña altura interior que dominaba el denominado Camí des Parpers, principal vía terrestre de unión de la depresión prelitoral y la costa de Barcelona desde la Antigüedad (Sánchez et al. 1995: 3-5). Las estructuras identificadas hasta el momento corresponden a algunas edificaciones aterrazadas y múltiples silos de gran tamaño que testimonian la vocación agrícola del enclave. Sin embargo, a pesar de no haberse localizado estructuras alfareras (hornos o testares), la presencia de algún prisma de tipo semicircular (Sánchez et al. 1995: 9 $\left.n^{\circ} 74 / 4\right)$ parece indicar que los habitantes de la aglomeración rural no sólo almacenaron grandes excedentes cerealísticos sino que también realizaron otras actividades artesanales-comerciales como la producción cerámica. Se trata de un nuevo indicio de la temprana aparición de los prismas en el área catalana, previa a la arribada de los contingentes militares bárcidas, y asimismo de la penetración del fenómeno tecnológico hacia las campiñas de la franja interior próximas a la costa.

En conexión con los hallazgos de Granollers, el taller costero localizado en la riera de Sant Simó (Mataró) parece remarcar el origen costero de esta tecnología en el ámbito catalán. En este asentamiento fueron documentados hasta tres hornos y varios testares correspondientes a un importante alfar de época ibérica (Pons 1983: 198, Ribas 1984: 281), dedicado esencialmente a la producción de ánforas y cerámicas comunes. El uso de prismas en esta alfarería queda atestiguado por la presencia de varios ejemplares entre los materiales recuperados en la excavación del horno más septentrional, correspondiendo las piezas a la morfología de tipo semicircular con secciones triangulares bastante regulares (C1). La datación de la actividad de este taller es conflictiva, dada la publicación parcial de un pequeño conjunto de materiales sin conexiones estratigráficas claras (Pons 1983: 188-197), así como ante la falta de materiales con cronologías ajustadas per se, si bien la tipología de las producciones locales y la presencia de una ánfora corintia $A^{\prime}$ parecen sugerir una actividad centrada en los siglos IV/III a.n.e.

En definitiva, estos hallazgos del área catalano-levantina y de Iberia meridional descritos ponen de relieve cómo en esta etapa tardo-clásica y helenística, el uso de soportes semilunares era un procedimiento tecnológico relativamente frecuente en buena parte de la península, extendido en alfarerías de una identidad étnica, cultural y económica muy diversa, cuyas conexiones son en muchos casos difíciles de establecer en base a la información disponible (fig. 2). Como ya adelantamos, resulta por ahora imposible descartar (especialmente para la fachada oriental peninsular) una influencia de las cuñas usualmente utilizadas en alfarerías griegas, sobre todo teniendo en cuenta la proximidad de Emporion-Rhode o Massalia, ni tampoco una extensión de estos usos desde el área púnica o ibérica de la mitad sur-sureste de la península, bien por vías de contacto comercial o bien bajo el manto de la ocupación cartaginesa o incluso de los propios romanos. Es asimismo significativo de esta fase, la persistente ausencia de estos prismas en otros focos de producción principales peninsulares, como el caso de Gadir, en cuyos numerosos talleres tardopúnicos no se han localizado evidencias de este tipo, confirmando, en cierta forma, la trayectoria vislumbrada para centurias precedentes y continuando también con la delimitación "por exclusión" de una tradición alfarera propia, fuerte y definida. 


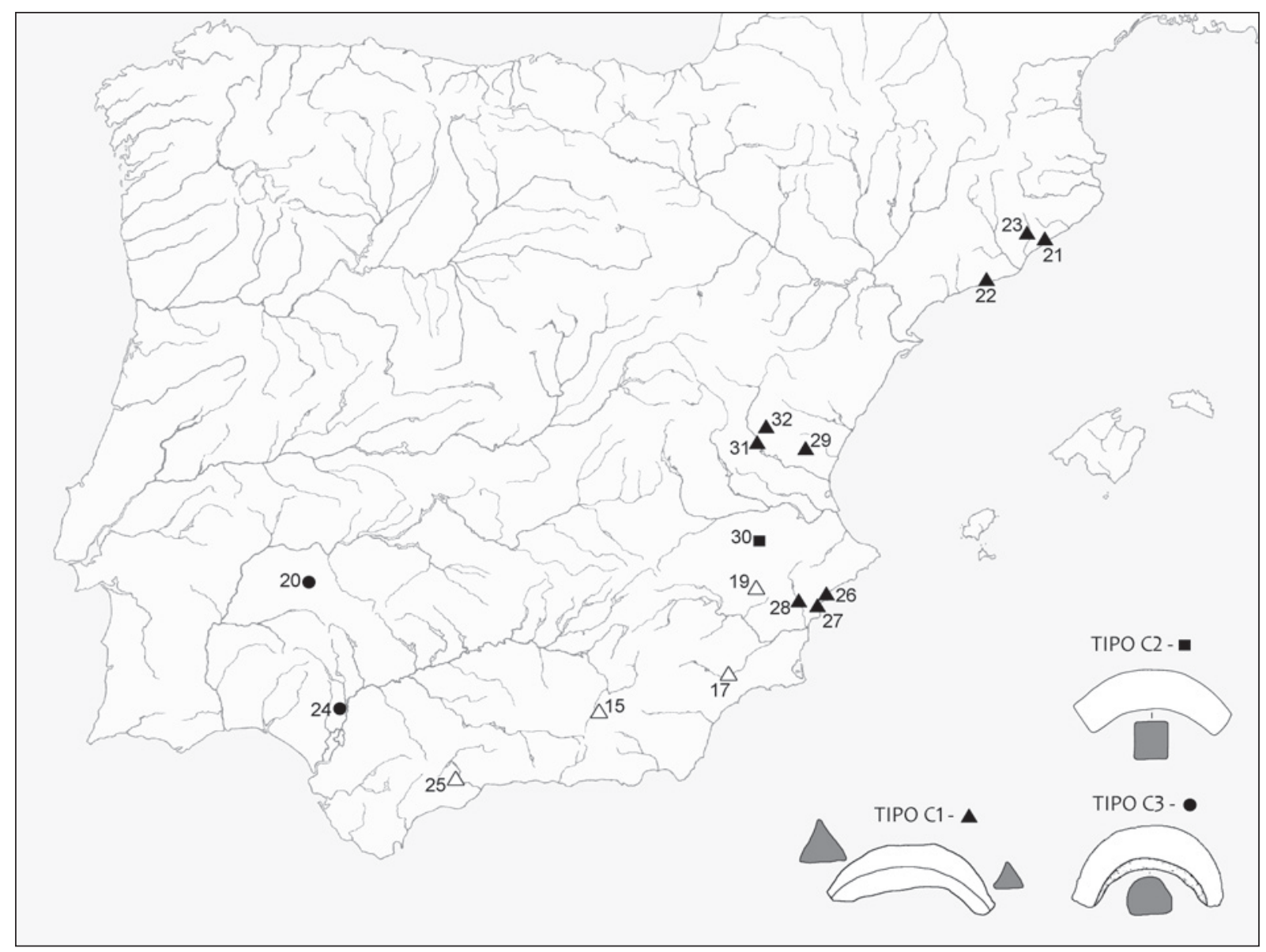

Figura 2. Dispersión de las diversas variantes de prismas del Tipo C.

\section{LOS PRISMAS FENICIOS EN CONTEXTO MEDITERRÁNEO}

La problemática relacionada con el estudio de los elementos de soporte y distanciadores usados en labores alfareras (especialmente en la cocción) en talleres del mundo griego e itálico excede con mucho los objetivos definidos para este trabajo, pues el volumen de documentación y de publicaciones disponibles es notable y cuenta con una larga tradición. Sin embargo, como ya se adelantó en la introducción, resulta de gran interés acercarnos a su origen y evolución, pues encontramos en esta tecnología alfarera sugerentes conexiones que permiten llenar algunos vacíos existentes en la información disponible para el caso de los prismas fenicio-púnicos. Por ello, intentaremos ofrecer ahora una somera retrospectiva de los datos con que contamos acerca de los soportes/distanciadores usados en los alfares griegos e itálicos, haciendo especial hincapié en aquellas morfologías relacionadas con la problemática específica de los prismas.

Ha sido precisamente la enorme variedad de elementos vasculares o fabricados a mano o a molde implicados en estas tareas de estabilización, soporte $\mathrm{y}$ apilamiento, uno de los ejes sobre los que ha basculado la investigación en el mundo griego, teniendo sólo una pequeña fracción de los tipos documentados relaciones morfológicas o funcionales con los prismas que constituyen el objeto de este trabajo. Esta diversidad formal, aunque ya esbozada en trabajos anteriores, ha sido parcialmente sistematizada en una tesis doctoral reciente (Hasaki 2002), centrada en el análisis de la producción cerámica en Grecia durante la Antigüedad. A partir de testimonios ya publicados y de informaciones inéditas, esta autora ha propuesto un marco tipológico general para estos ítems, diferenciando un total de siete categorías principales de las que las cinco primeras pueden considerarse verdaderamente útiles diseñados de 
forma específica para estas funciones auxiliares, mientras que las dos últimas estarían caracterizadas por un uso puntual u oportunista de diversos objetos con estos mismos fines. Dicha propuesta tipológica de kiln furniture (Hasaki 2002: 91-98) incluye los denominados soportes teardrop-shaped (tipo a), trípodes (tipo b), formas trapezoidales de volumen variable (tipo c), los soportes o cuñas denominados $L$-shaped (tipo d), diversas versiones de clay rings/cylinders (tipo e), a los que habría que añadir elementos de morfología piramidal (tipo f, que incluiría el uso secundario de pesas de telar como soportes) y una utilización también de tipo oportunista de cualquier tipo de fragmento cerámico como elemento distanciador o de soporte (tipo g). Estas grandes familias definidas por Hasaki serían a grandes rasgos las más abundantes y significativas entre los elementos subsidiarios de los hornos griegos, alcanzando buena parte de los tipos una enorme perduración en el tiempo hasta enlazar con la producción de época romana y bizantina, sin duda debido a su pertenencia a grupos tecnológicos básicos de amplia difusión en variadas culturas y épocas en el marco de unas técnicas como las alfareras, cuyos mínimos parecen haber sido compartidos en múltiples puntos del planeta. Como veremos, muchos de estos tipos que podemos considerar básicos en la tecnología alfarera antigua (significativamente, los c y f de la tipología de E. Hasaki) corresponden a los que presentan mayores analogías con nuestros prismas. En cualquier caso, creemos que esta ordenación formal propuesta para Grecia continental y el Egeo supone un paso importante en la dirección de un estudio profundo de estos elementos secundarios en el ámbito griego oriental, estableciendo un marco inicial de referencia para algunos de los centros alfareros más importantes del mundo arcaico, clásico y helenístico.

Una de estas referencias clave la constituyen las alfarerías de Atenas, hasta fechas recientes mucho menos conocidas que sus propias producciones (una síntesis en Monaco 2000), pero que en los últimos años han proporcionado una ingente y contextualizada información sobre su evolución espacial, acerca de la configuración de hornos y talleres, y de igual modo sobre el uso de elementos técnicos auxiliares como soportes y distanciadores. Entre los avances más destacados de la trayectoria reciente de estas investigaciones sobre los ergasteria atenienses podemos situar la caracterización de talleres activos en época geométricaorientalizante en el área posteriormente ocupada por el ágora de época clásica (Papadopoulos 2003), entre cuyos testimonios han podido localizarse restos de hornos, moldes, desechos deformados, piezas de prueba y asimismo algunos elementos fragmentarios clasificados como soportes de horno (kiln firing supports). A pesar del elevado número de contextos, este tipo de evidencias se restringen a unas pocas piezas fragmentarias que ilustran quizás los precedentes del variado elenco de soportes, cuñas y distanciadores de épocas posteriores: por un lado, encontramos un posible clay ring $\left(\mathrm{n}^{\circ}\right.$ 58 del catálogo; Papadopoulos 2003: 75-76, fig. 2.27), pero sobre todo destacamos dos fragmentos de elementos macizos aristados en forma de paralelepípedo $\left(\mathrm{n}^{\circ} 86\right.$ y 102 del catálogo; Papadopoulos 2003: 106, 122-123, figs. 2.46 y 2.59, respectivamente), cuya morfología se acerca a los prismas fenicios y que parecen tener paralelos en el área del Ágora en otros hallazgos de posible origen alfarero (depósito S17:12, identificado como potencial testar). El posible soporte en forma de anillo proviene del contexto Pozo L11:1 (datado en época geométrica inicial-evolucionada), mientras que los restos de soportes angulares ¿o cuñas? fueron localizados respectivamente en los depósitos L6:2 (Geométrico medio) y N11:5 (Geométrico tardío), señalando el posible uso de elementos auxiliares en la cocción ya en momentos muy tempranos de la producción ateniense (fig. 3/1-3).

J. K. Papadopoulos dedica un breve espacio monográfico a estos posibles integrantes del grupo kiln furniture (Papadopoulos 2003: 216-217), destacando la dificultad de atribución ante tan escasa muestra fragmentaria e incidiendo especialmente en el debate sobre la verdadera dimensión de su uso en los talleres de época pre-arcaica:

[...] The low number of true kiln firing supports in the Early Iron Age deposits, especially when compared to the much larger quantities of test-pieces, as well as wasters and production discards, is a notable feature. (...) The dearth of firing supports in Early Iron Age and in many Archaic and Classical kiln sites is due to the nature of the black paint or gloss (Papadopoulos 2003: 217).

En efecto, el autor postula a partir de estos exiguos testimonios y de otros centros alfareros griegos como Torone (Papadopoulos 1989) o Pharos en Thasos (Peristeri et al. 1985), el escaso protagonismo que a su juicio tendría el uso de soportes o distanciadores en la generalidad de centros alfareros griegos de época arcaica, clásica o helenística; ligando este supuesto a la ausencia de necesidad debido a la calidad del barniz negro griego y el que este permitía mantener los estándares a pesar de no separar los vasos durante la cocción. Estas características de los barnices griegos habrían 


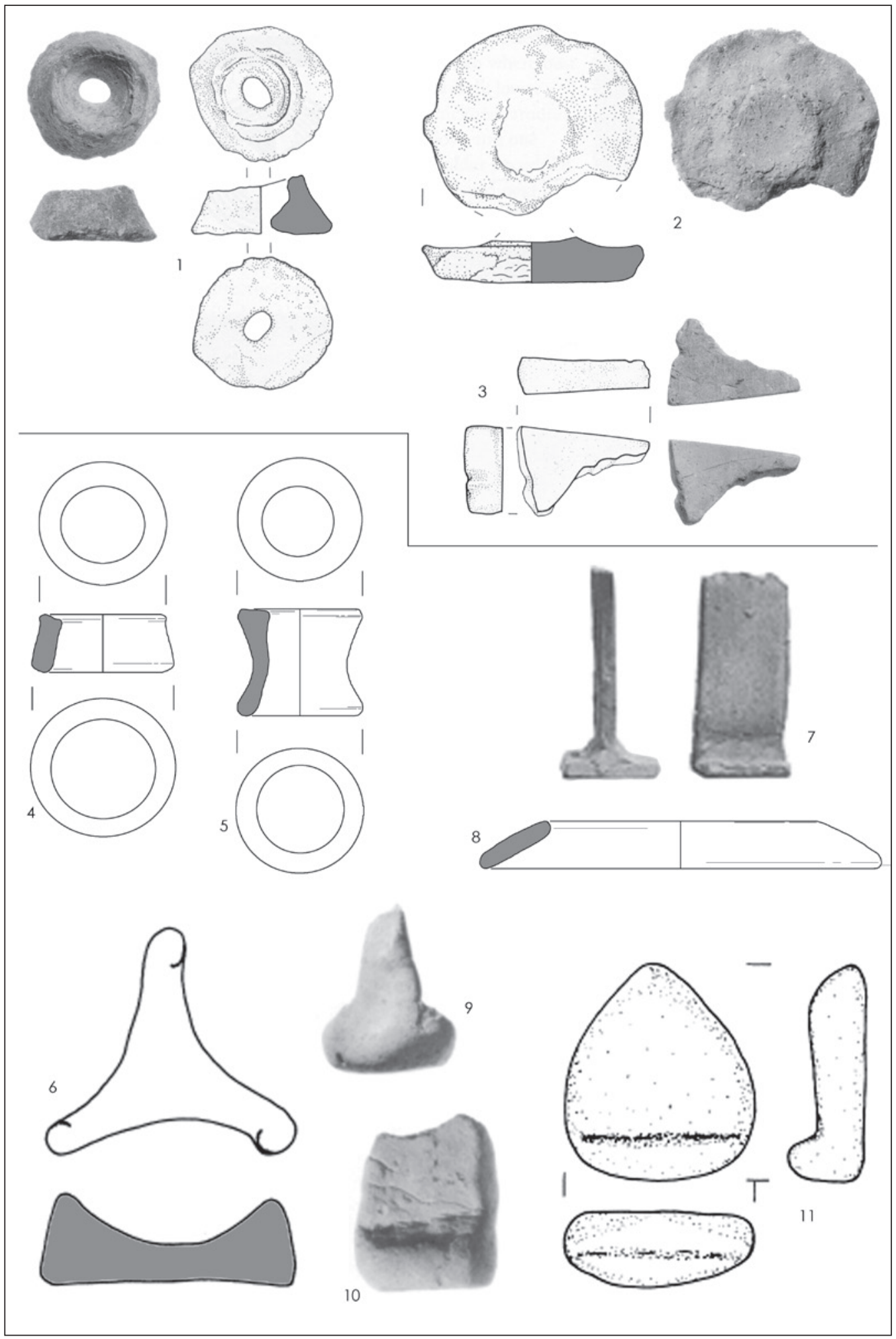

Figura 3. Tipología de algunos elementos auxiliares documentados en Atenas: 1-3, hallazgos de época geométrica (a partir de Papadopoulos 2003); 4-11, diversos tipos empleados en época clásica-helenística (a partir de Papadopoulos 1992) (distintas escalas). 
motivado la carencia de razones para generar un sistema de carga complejo, pudiendo apilarse muchos tipos de vasos, unos directamente encima de otros, $y$, en caso necesario, recurriendo a la reutilización de fragmentos cerámicos o pesas piramidales de telar como alternativa puntual. Como veremos, esta hipótesis parece encontrar actualmente cierto acomodo para la producción de época geométrica, pero no así para la de época clásica o helenística, periodos en los que el uso de elementos auxiliares parece nota común tanto en Grecia continental como en ambientes coloniales.

De hecho, las evidencias proporcionadas por la propia polis ateniense parecen ser un argumento contundente a este respecto, con un creciente número de soportes de tipo diverso procedentes tanto del área del Ágora como del Kerameikos o de otros talleres alfareros suburbanos. El propio Papadopoulos (1992) había dado ya a conocer un destacado conjunto de soportes de los tipos teardrop-shaped, trípodes de diverso tamaño, clay rings, T-shaped y algunos otros elementos más dudosos (fig. 3, 4-11), en su mayoría procedentes de diversos contextos del ágora de Atenas datados entre época tardoclásica y, sobre todo, romana y bizantina (Cracolici 2003: 20). Estos hallazgos, aunque desligados en general de contextos alfareros definidos, parecen dejar claro la importancia y uso habitual de este tipo de elementos en los hornos atenienses de época tardoclásica y helenística, con una perduración posterior muy destacada de muchos de los tipos. En este sentido, destacan también los hallazgos de época clásica dados a conocer recientemente correspondientes a pequeños trípodes y sobre todo anillos a torno (a veces con inscripciones pintadas o grafitos precocción), en su mayoría documentados en el ergasterion excavado en el área Lenormant relacionada con el camino hacia el Kolonos Hippios (Monaco 2000: 85-95, tab. 40-59). En resumen, todos estos testimonios citados parecen apuntar a un tímido uso de soportes o distanciadores desde época geométrica, práctica profusamente desarrollada sobre todo a partir de época clásica y helenística en las alfarerías atenienses.

Los talleres dedicados a la producción de tégulas y materiales constructivos diversos localizados en el cinturón periurbano al norte del recinto murado de Corinto (Greek Tile Works) han proporcionado también destacados testimonios arqueológicos sobre el uso de elementos auxiliares a las tareas de cocción de estas producciones de gran volumen y difícil manejo. La producción cerámica se desarrolló en este punto de la ciudad probablemente desde los inicios del s. VI a.n.e., habiéndose documentado en las excavaciones los restos de varias estancias y dos hornos cuya sucesiva actividad parece poder situarse al menos entre la segunda mitad del s. VI y el IV a.n.e., compaginando la producción de materiales constructivos, terracotas arquitectónicas y otras categorías vasculares. La intervención en los propios hornos, así como en otros depósitos cerrados situados en el entorno de los talleres, ha permitido documentar un notable conjunto de soportes, cuñas y distanciadores de diversos tipos usados en las diversas etapas de actividad (Merker 2006: 21-22): destaca la presencia de trípodes de gran formato, de cuñas tipo L-shaped y de numerosos prismas cuadrangulares y distanciadores piramidales de tamaño diverso (fig. 4, 1-10), morfologías documentadas en contextos datados en fechas anteriores al último cuarto del s. V a.n.e.; adicionalmente, hay que unir a estas formas la presencia de soportes del tipo teardrop-shaped, que en base a paralelos ofrecidos por otros contextos corintios han sido vinculados a la fase más reciente de la actividad y a la etapa de producción del segundo horno, probablemente durante el s. IV a.n.e. Todos estos soportes estarían hechos a mano, utilizando las mismas pastas que las usadas para otros materiales cocidos en el taller, presentando generalmente un aspecto friable propio de exposiciones repetidas a las altas temperaturas del interior de los hornos. Para momentos posteriores, los indicios disponibles son mucho más escasos por ahora y con menos apoyos contextuales, siendo probable la utilización de soportes de "tipo cuña" durante los siglos IV y II a.n.e. (Roebuck 1951: 121, lámina 32, Kalogeropoulou 1970: 433, fig. 9) y también el uso de soportes del tipo clay rings de cierto tamaño, si bien estos últimos no pueden vincularse inequívocamente a la producción cerámica (Cracolici 2003: 20).

En este repaso a las evidencias de Grecia continental también podemos incluir los interesantes hallazgos alfareros documentados frente a la costa macedonia en Pharos (Thasos), donde pudieron ser excavados los restos de un taller alfarero de época arcaica dotado de dos hornos de planta circular de dimensiones medias (Peristeri et al. 1985). En lo que atañe al uso de elementos auxiliares para la cocción en este taller, hay que señalar que junto a los ya conocidos clay rings, vinculados al apilamiento en columna de vasos del mismo tipo, se documentaron también piezas de morfología prismática cuadrangular (Peristeri et al. 1985: 32 figs. 3-4, Papadopoulos 1992: 215 nota 42), no muy distintas de las ya descritas para el caso de Corinto y, en definitiva, de los prismas fenicios contemporáneos.

Aunque la información suministrada por Grecia continental es desde luego muy sustanciosa, actualmente la mayoría de datos referentes a esta cuestión de los elementos auxiliares en las alfarerías griegas 


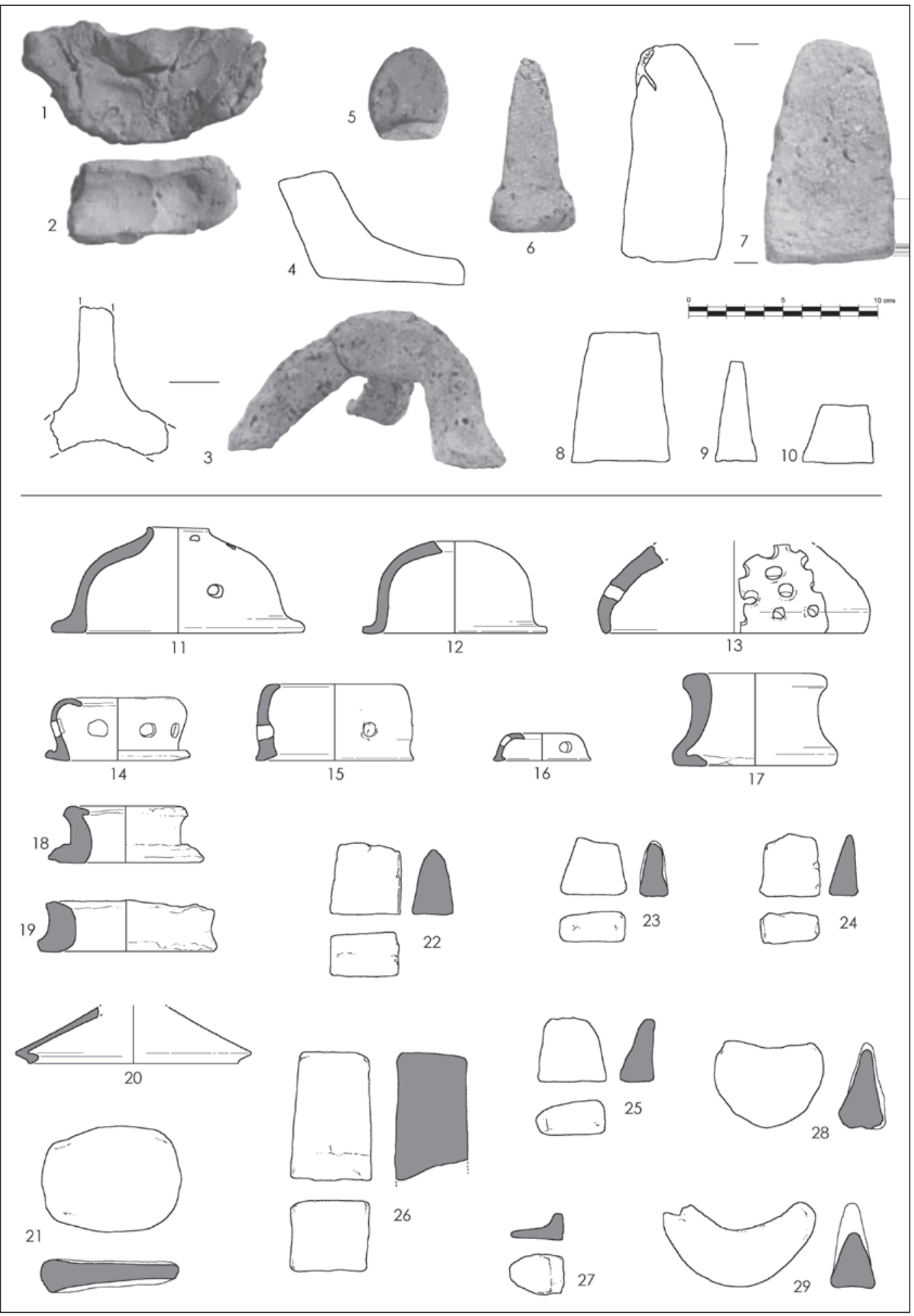

Figura 4. 1-10: Tipos de soportes/separadores empleados en los talleres de Corinto (a partir de Merker 2006); 11-29: selección de los principales tipos de soportes, separadores y cuñas documentados en las oficinas de producción de Tarento (a partir de Dell'Aglio 1996) (distintas escalas). 
la encontramos en los diversos talleres localizados en Magna Grecia, área donde se ha venido incidiendo con mayor atención sobre esta temática en las últimas décadas y que parece haber tenido una especial vivacidad en el uso, adaptación y evolución de dichos sistemas de carga de los hornos. De entre los numerosos asentamientos coloniales que han aportado testimonios de actividades alfareras destaca a este respecto el caso del kerameikos de Metaponto, excavado de forma prácticamente sistemática por F. D'Andria entre 1972-1977 pero sólo parcialmente publicado. Incluye restos de instalaciones de taller, numerosos testares y varios hornos de planta circular cuya actividad se ha podido situar entre la etapa arcaica y -sobre todo- los ss. V/IV a.n.e. La reciente publicación de la tesis doctoral de V. Cracolici (2003) ha supuesto un revulsivo en este estudio del cerámico metapontino, trascendiendo de los estudios de materiales clásicos ligados a los centros productores y planteando una metodología centrada en el análisis de los sostegni di fornace, en la extracción a través de estas evidencias de inferencias tecnológicas y sobre los procesos de manufactura en clave diacrónica. Sobre la base de un riguroso estudio de base estratigráfica, este investigador ha dividido los soportes de Metaponto en siete grupos principales (fig. 5): grupo I (cilindrici), grupo II (a campana), grupo III (ad anello), grupo IV ( coperchio), grupo V (coperchi campaniformi), grupo VI (a cuneo) y grupo VII (a staffa). En lo que ahora nos atañe, interesa detenernos especialmente en los dos últimos grupos, que incluyen algunos subtipos ya tratados a propósito de Atenas o Corinto y que, como veremos, presentan evidentes conexiones formales y funcionales con algunos de los tipos definidos de prismas fenicios. En concreto, el grupo VI engloba tanto a ejemplares del tipo teardrop-shaped (VI-A1) como a verdaderas cuñas de sección triangular (VI-B1), ambos datados entre los siglos VI a IV/III a.n.e.; por su parte, el grupo VII estaría compuesto exclusivamente por elementos realizados a mano en forma de media luna con secciones tendentes a rectangulares o triangulares, muy similares a los tipos $\mathrm{C} 1 / \mathrm{C} 2$ de la tipología que proponemos para los prismas fenicios (v. supra), datándose su vigencia entre los siglos VI a IV a.n.e. Los datos de Metaponto son por todo ello muy sugerentes, pues amplían notablemente el catálogo morfológico de soportes y distanciadores documentados en Grecia continental y añaden un decisivo puente formal entre los útiles alfareros griegos y los prismas que constituyen el objeto de estudio de este trabajo, aspecto sobre lo que volveremos más adelante.

Pero no sólo los talleres del área urbana metapontina están proporcionando una riquísima documentación sobre el uso de soportes y distanciadores, pues también en fechas recientes las actividades de prospección y excavación puntual en diversos puntos de su chora parecen refrendar la importancia de esta práctica artesanal. En concreto, debemos resaltar los resultados preliminares obtenidos por el proyecto de investigación dirigido por la Universidad de Milán en el área de Pisticci-Ferrandina (Castoldi 2008), que en la campaña de 2008 han puesto al descubierto los restos de una alfarería rural de época tardoclásica o helenística localizada en la zona al noroeste de Masseria Tredicicchio. Los resultados de estas excavaciones se encuentran aún en proceso de estudio, si bien los primeros datos dados a conocer (Castoldi 2009, actualizados correspondientes a las diversas campañas así como otras informaciones y bibliografía del proyecto) sobre los materiales asociados parecen poner de relieve el uso de abundantes soportes con paralelos evidentes en los repertorios de Metaponto o Tarento, destacando tanto los denominados a coperchi (con múltiples perforaciones) como cuñas (a tacco) aparentemente encuadrables en el tipo VI-B1 metapontino. Estos datos aún preliminares parecen reforzar la documentación aportada anteriormente por otro horno rectangular excavado en el área de Contrada Torretta de Pisticci, activo entre los siglos VI/V a.n.e., al cual se asociaban soportes a cuneo y a staffa de los grupos VI-VII de la tipología de Metaponto (Cracolici 2003: 97-98).

No menos destacada, aunque sí apenas sistematizada, resulta en este mismo sentido la rica documentación aportada por recientes actividades arqueológicas desarrolladas en el área urbana de Tarento (Dell'Aglio 1996: 51-67, Cracolici 2003: 22), que han puesto al descubierto restos de diversas oficinas de producción cerámica activas especialmente durante los siglos V/ IV a.n.e. Entre las evidencias muebles ligadas a estos centros productores destaca el amplísimo conjunto de soportes, cuñas y distanciadores recuperados que, en buena medida, repiten muchos de los grupos tipológicos y subtipos definidos para el cerámico metapontino (fig. 4, 11-29): encontramos un buen número de variantes de clay rings (soportes ad anello, a campana $y$ cilindrici, grupos I-II-III) junto a algunas versiones particulares de elementos a coperchio (grupo IV) y quizá adaptaciones a pequeña escala de coperchi campaniformi (grupo V), presentando algunos individuos inscripciones pintadas y detalles morfométricos muy particulares. Sin embargo, resulta de mucho mayor interés para nuestras investigaciones la no menos abundante presencia de otros tipos de soportes, algunos de ellos también documentados en Metaponto, Atenas o Corinto: se trata por una parte de piezas del tipo 


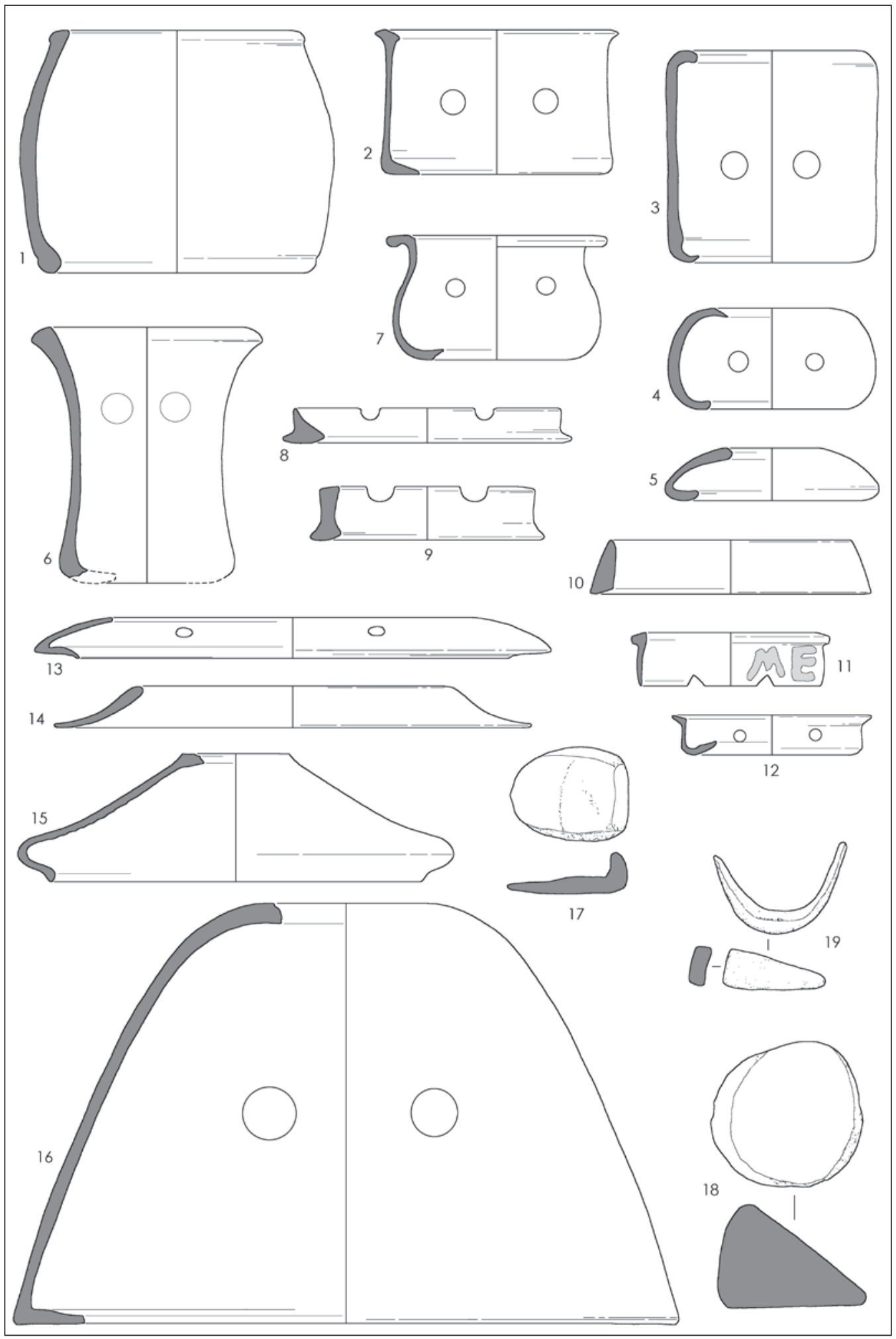

Figura 5. Resumen de los principales tipos y familias de sostegni di fornace recuperados en los diversos testares del kerameikos de Metaponto (a partir de Cracolici 2003): 1-3, cilindrici; 4-5 y 8-14, ad anello; 6-7, a campana; 15, a coperchio; 16, a coperchio campaniforme; 17-18, a cuneo; 19, a staffa (distintas escalas). 
teardrop-shaped, pero sobre todo de un variado elenco de cuñas de tipo prismático tanto de sección triangular como cuadrangular, representadas en diversos tamaños, y quizá relacionadas con algunas placas de mayor superficie y perímetro más redondeado. Estas cuñas (grupo VI-B1 de Metaponto) presentan claras analogías formales con los prismas fenicios del Tipo A (v. supra), aunque, como en el caso corintio, se aprecia en buena parte de los ejemplares ilustrados una regular tendencia a conformar los cuerpos macizos una estructura troncopiramidal. Con un interés similar, cerraría el grupo de sostegni di fornace localizados en Tarento un conjunto de elementos con forma de media luna y sección triangular que encaja perfectamente en nuestro Tipo $\mathrm{C} 1 \mathrm{de}$ finido para los prismas fenicio-púnicos. Merece la pena destacar que este tipo de soportes parece que contó en el área apula con una fuerte raigambre en las tradiciones artesanales, ya que encontramos testimonios de la continuidad de su uso, mostrando características físicas apenas diferenciadas, en otros contextos alfareros de época romano-republicana. En concreto debemos resaltar las evidencias aportadas por las investigaciones en algunas alfarerías relacionadas con la antigua ciudad de Herdonia, tanto vinculadas con un horno de planta rectangular quizá relacionado con la cocción de tegulae localizado bajo el anfiteatro, como otros vertidos propios de un testar (próximos a la Domus B), en los que se documentaron tanto desechos de cocción como los citados soportes en forma semilunar (De Stefano 2008: 128, fig. 15). Ambos horizontes parecen situar la actividad productiva en un lapso no determinado entre los siglos II y I a.n.e., lo que da buena cuenta de este arraigo de los soportes análogos a nuestro tipo $\mathrm{C} 1$ en la zona apula.

Otros muchos enclaves magnogrecos también han proporcionado amplias evidencias de producción cerámica, localizándose en buena parte de ellos soportes y distanciadores de varios tipos: en Heracleia destacan los testimonios recuperados tanto en la Colina del Castillo como en la denominada "ciudad baja" (Adamesteanu 1970 y 1974, D’Agostino 1972); en el kerameikos de Laos se ha documentado una intensa actividad alfarera relacionada con soportes del grupo II datados desde el s. IV a.n.e. (Greco y Guzzo 1978, Greco et al. 1989, Munzi 2009); asimismo, destacan los hallazgos de Locri-Centrocamere, con múltiples talleres alfareros insertos en la trama urbana ortogonal dedicados fundamentalmente a la producción de cerámicas comunes y otras formas no barnizadas (Cuomo di Caprio 1974, Barra Bagnasco 1976 y 1984), en los cuales se ha podido aislar el uso de cuñas del tipo VI-A1 (teardrop-shaped) en época clásica y helenística. Por el momento, estos otros talleres no han proporcionado nuevas muestras de la utilización de cuñas o medias lunas similares a las documentadas en Metaponto o Tarento y próximas a los prismas de nuestra tipología.

Aunque la información disponible es sensiblemente menor, actualmente la situación de los talleres cerámicos siciliotas parece estar en la misma línea que la zona sur de la península itálica, si bien de nuevo la documentación referida a soportes de tipo a cuneo o a staffa es prácticamente nula, siendo los más usados los anillos y cilindros acampanados de los grupos II-III de Metaponto (Cracolici 2003). En este grupo debemos incluir un posible vertedero de alfarería documentado en Gela (Adamesteanu 1954: 129-132) y algunas evidencias procedentes del relleno de una cisterna situada al sur del Olimpieion de Agrigento (De Miro 1963: 155158, fig. 71-73) con un relleno datado a partir del s. IV a.n.e. Otras evidencias de interés fueron localizadas en un posible contexto votivo del barrio oriental de Himera (Stazio 1965), sellado por los derrumbes asociados a la destrucción de la ciudad en 409 a.n.e. que incluía un nutrido conjunto de soportes de forma acilindrada, acampanada o de anillo, algunos con inscripciones o marcas incisas precocción. En este grupo de hallazgos sicilianos es necesario resaltar también un posible ejemplo (análogo a la interacción entre fenicios y tartesios-turdetanos) de transferencia tecnológica al mundo indígena: se trata de los hallazgos relacionados con un alfar documentado en el centro elimo de Entella en el que un horno datado en los últimos decenios del s. VI a.n.e. se asociaba a soportes ad anello y formas macizas denominadas piramidette fittili (Guglielmino 1992 y 2000: 703, lámina CXXIII.4). Estos hallazgos de Entella, que incluyen numerosas importaciones griegas asociadas a los hornos, parecen testimoniar una rápida introducción de estas técnicas de optimización de la carga de los hornos cerámicos hacia ambientes indígenas desde las colonias griegas siciliotas, un proceso similar al que pensamos debió ocurrir en el caso ibérico partiendo de los asentamientos coloniales fenicios.

Las áreas fuertemente helenizadas de Italia meridional y de la Campania también han ofrecido testimonios referentes al uso de técnicas complejas para el apilamiento de los vasos durante la cocción, en especial ligadas a la fabricación de cerámicas de barniz negro. Este es el caso tanto de algunas investigaciones recientes en el kerameikos de Paestum (Pontrandolfo 1996: 252) como de las excavaciones realizadas en el área de la basílica y Vía Marina de Pompeya (Arthur 1986: 3233, fig. 3.4-5), en este último caso, relacionadas con un 
vertedero de alfar vinculado a la producción de cerámicas de barniz negro datado hacia fines del s. IV a.n.e. y/o inicios del III a.n.e. También de este último lugar, podemos señalar otras evidencias ligadas a hornos cerámicos de época mucho más tardía localizados en la insula 5, 2 de la regio I, muy alterados por ocupaciones de época imperial ligadas a tintorerías, que testimonian la perduración del uso de separadores en forma de anillo y trípodes también en relación con la cocción de cerámicas comunes diversas (Cavassa 2009: 96-102, fig. 5-6). En ambos casos, parece que los soportes alfareros usados habrían correspondido fundamentalmente a modelos acilindrados o ad anello, propios de centros dedicados a la producción masiva de cerámicas barnizadas, seguramente utilizados en centurias posteriores en las numerosas oficinas productoras activas en época romano-republicana en la región. Otro ejemplo de gran interés que podemos añadir a estos dos casos es el del hábitat de época samnítica de Fratte, donde tanto investigaciones en el área de la acrópolis (Greco y Pontrandolfo 1990) como en otras zonas más periféricas del asentamiento han registrado la presencia de indicios relacionados con la producción cerámica como desechos o soportes/distanciadores. Destacan a este respecto las investigaciones recientes, que han incluido la excavación de un pequeño horno alfarero posiblemente dedicado a la cocción mixta de cerámicas barnizadas y comunes, en cuyo relleno y alrededores se documentó un notable conjunto de distanciadores cilíndricos y $a d$ anello así como numerosas cuñas similares a las vistas para los casos magnogrecos (Serritella 2011, especialmente fig. 103b).

De mayor relación con la cuestión de los prismas de origen fenicio resultan algunos datos procedentes de Italia central y el área etrusca, cuya dinámica general parece encajar sin problemas en el esquema general que se ha delineado a partir de la exposición de los datos de Grecia continental, Magna Grecia o Sicilia. Siguiendo un orden cronológico en la exposición de datos hay que destacar la reciente documentación de elementos auxiliares en algunas estructuras fornáceas documentadas junto al recinto murario de la ciudad de Tarquinia, talleres volcados a la producción de material constructivo (tégulas específicamente) durante el s. VII a.n.e. (Baratti y Mordeglia 2009). En lo referido al uso de soportes o distanciadores, tanto en algunos niveles vinculados a la cimentación de la propia cinta muraria, como en conexión a las propias estructuras de combustión, pudo recuperarse un destacado conjunto de «[... manufatti fittili cotti di forma troncopiramidale, con altezza variabile dai 6 ai $12 \mathrm{~cm}$ ca. e a volte con la base volutamente ispessita» (Baratti y Mordeglia 2009: 8990, fig. 14, notas 17-18). Estos ítems de morfología troncopiramidal fueron relacionados por sus excavadores con distanciadores que habrían servido para facilitar las tareas de apilamiento y ajuste de las tégulas en el interior de la cámara de cocción del horno.

La tipología de estos posibles distanciadores piramidales de Tarquinia parece encontrar correspondencias claras en otros hallazgos del área etrusca, caso de la zona de Plaza de Armas de Faenza (Parmeggiani 1982), del entorno de Módena (Calzolari 1992) y en la región de Versilla (Paribeni 1990), datados también en época arcaica o tardoarcaica, lo que supone por el momento un reducido grupo de centros productores en los que se utilizó este tipo de soportes pero, a la vez, también un sugerente indicio de la extensión de esta tecnología a través del territorio etrusco. Estos elementos troncopiramidales documentados en Etruria en contextos alfareros parecen encontrar también paralelos muy cercanos en talleres griegos ya mencionados aquí, caso de los hornos productores de material constructivo de Corinto (Merker 2006: 21-22, 31, n 18-19 del catálogo), de algunos soportes también relacionados con la producción de tégulas en hornos arcaicos de Pharos en Thasos (Perreault 1990) o de las pirámides cerámicas localizadas en algunos hornos del asentamiento siciliano de Entella (Gugliemino 2000), no estando demasiado alejados en cuanto a estructura general de algunos soportes en forma de paralelepípedo o a cuneo documentados en Metaponto o Tarento (Cracolici 2003).

Otro posible paralelismo para el uso de estas pirámides con fines alfareros podría encontrarse en la atribución a la actividad de Metaponto de una ofrenda votiva dedicada a Heracles por parte del artesano Nikomachos inscrita sobre un elemento cerámico piramidal datado hacia mediados del s. VI a.n.e., el cual ha sido puesto en relación con los conocidos argoi lithoi habituales del santuario metapontino de Apolo (Guarducci 1974, D’Andria 1975: 446, nota 51, Cracolici 2003: 128). Se trata desde luego de un argumento indirecto, pero que podría reforzar el protagonismo que parece observarse de estos elementos más sólidos de tipo piramidal o cuñas en las etapas pre-clásicas en los talleres griegos o fuertemente helenizados.

Aunque no poseemos argumentos directos, estos indicios y la propia dinámica cultural etrusca parecen apuntar a una temprana influencia helénica en la tecnología alfarera de la región, más evidente en el caso de Tarquinia al estar ligada a la producción de tégulas, otro elemento propio de la edilicia griega de la época. Lo cierto es que a pesar de contarse ya con un destacado volumen 
de talleres alfareros de la Edad del Hierro en Etruria e Italia central (una síntesis en Nijboer 1998: 50-124, v. Boitani et al. 2009 y Ciacci et al. 2009, con amplia bibliografía anterior), el estudio de estos centros productores ha prestado escasa atención a este tipo de elementos auxiliares, lo que no permite valorar por el momento la verdadera dimensión y evolución de la utilización de soportes y distanciadores en la zona. Un indicio positivo en este sentido lo proporcionan los resultados preliminares de las excavaciones de la officina de Guasticce-Ca' Lo Spelli ubicada en el entorno de Livorno, en la cual en un horizonte datado en los siglos II/I a.n.e. se localizaron "[...] dodici blocchetti fittili a forma di parallelepipedo" (Ducci et al. 2006: 242), interpretados por sus excavadores como posibles distanciadores usados en los cercanos hornos alfareros. En cualquier caso, estos indicios aún débiles nos hacen sospechar que un rastreo sistemático más profundo de este tipo de evidencias en talleres etruscos o centroitálicos ya excavados o en curso de investigación, podría engrosar notablemente el mapa de dispersión de estas prácticas artesanales y aportar mejores apoyos contextuales para valorar las virtuales evoluciones tipológicas y tendencias de uso de los diversos tipos de soportes en tono diacrónico.

Por el momento, a esta cuestión del uso de distanciadores prismáticos o piramidales, podemos añadir algunos datos referidos a la utilización de otros tipos de soportes frecuentemente ligados a aquellos en, por ejemplo, los talleres magnogrecos. En efecto, resulta de interés resaltar el hecho de que, desde época tardoclásica y sobre todo en momentos helenísticos, parece asistirse a una generalización del uso en los talleres de la zona de soportes de tipo acilindrado o ad anello especialmente en relación a la producción estandarizada y masiva de cerámicas de barniz negro. Buenos ejemplos de ello los encontramos en alfarerías del área de Rimini (Giovagnetti 1993: 120, fig. 6, 1995), en una estructura fornácea de Aesis datada entre mediados del s. III a.n.e. y la primera mitad del II a.n.e. (Brecciaroli 1998: 235 237, fig. 123), en hornos vinculados a la cocción de barniz negro en Spina (Sassatelli 1993: 214, Morel 1998: 87-89) y también en el centro productor de Marcianella en Chiusi (Mascione y Aprosio 2003: 269-270). La utilización de este tipo de soportes y de otros distanciadores de diversa tipología en ámbito noritálico y también narbonense parece bien atestiguada por evidencias aún excesivamente dispersas, caso de algunas piezas documentadas en los talleres de sigillata de Arezzo (Cuomo di Caprio 2007: 529, fig. 171) o los elementos auxiliares de Scopietto (Bergamini y Gaggiotti 2011: 343377 ), destacando las piezas prismáticas localizadas en el interior de un horno (B5) de época imperial en el taller narbonense de Sallèles d'Aude (Laubenheimer et al. 1979), muy similares a otros de los casos más antiguos tratados en este mismo apartado. Evidencias de época tardorrepublicana e imperial de esta misma zona del sur galo señalan la extensión del uso de elementos auxiliares, especialmente soportes en forma de anillo o trípode: por un lado, talleres urbanos de Narbona (Passelac 1992, Sánchez 2009: 477, fig. 6), y, por otro, evidencias de utilización de soportes ad anello en el taller de época augústea de Bram en relación a la fabricación de terra sigillata (Passelac 2001: 152, fig. 10; este autor sugiere que se trata de elementos de aire itálico importados a la Galia). Estos datos fragmentarios muestran a nuestro juicio, en su conjunto, la existencia de una generalizada preocupación en las alfarerías laciales-etruscas y del sur galo desde al menos los siglos V/III a.n.e. por la optimización de las cargas de los hornos a partir del uso de soportes y distanciadores de los mismos tipos en boga en otras áreas mediterráneas y, del mismo modo, las evidencias más recientes confirman la larga perduración posterior de muchos de los tipos usados ya desde esta fase prerromana.

Los asentamientos griegos ubicados en territorio peninsular han proporcionado hasta el momento una desigual información sobre el uso de este tipo de elementos auxiliares en sus talleres alfareros. Resulta desde luego significativo el caso de Emporion, en cuya palaiapolis han podido excavarse varios hornos de cronología arcaica centrados en la producción de cerámicas grises cuyas estructuras y espacios asociados no parecen haber proporcionado testimonios de la utilización de soportes o distanciadores (Aquilué 1999, Aquilué et al. 2001). Las excavaciones en el área de la neapolis también han suministrado interesante información sobre la producción cerámica de la ciudad en momentos helenísticos, en este caso ligados posiblemente a la producción de cerámicas comunes y quizá ánforas, si bien no se han publicado por ahora con amplitud dichos contextos ni se ha señalado la presencia de soportes o distanciadores (Tremoleda 2000: 28-32). Sin embargo, en el caso de la cercana Rhode sí contamos con datos mucho más explícitos sobre el mobiliario usado en las faenas de carga y apilamiento en el interior del horno: se trata de la reciente publicación de dos talleres dotados de sendos hornos ubicados en el "barrio helenístico" de la ciudad (quizá su Kerameikos), relacionados fundamentalmente con la fabricación de sus conocidas cerámicas de barniz negro. Entre momentos terminales del s. IV a.n.e. y los inicios del II a.n.e., en estos hornos se habrían usado un variado elenco de soportes y 
distanciadores de tipos muy próximos a los reconocidos en los talleres atenienses o magnogrecos, destacando especialmente el uso de anillos de módulo variable y pequeños cilindros, todos ellos elementos sólidos y muy funcionales propios de un momento de estandarización de la producción de barniz negro (Puig 2006: 527-537). A estos discos habría que sumar quizá otros elementos denominados "plaquetas", macizos y de sección rectangular (en algún caso con decoración esgrafiada o estampillada), que la autora señala como posibles objetos de uso complementario para las tareas de carga del horno o elementos relacionados con las pruebas y control de la temperatura durante la cocción (Puig 2006: 537 fig. 11.20). Resta señalar respecto a Rhode el que las recientes investigaciones han llevado a proponer que dicha colonia fuese fundada por Massalia en el s. IV a.n.e., lo que podría suponer un indicio indirecto para sospechar que también en el centro matriz de dicho proceso se habrían utilizado soportes/ distanciadores al menos para la producción de vajilla barnizada. En cualquier caso, resulta de gran interés la constatación de la extensión del uso de este tipo de soportes y elementos macizos en talleres peninsulares griegos, al mismo tiempo que el registro disponible señala la inexistencia en ellos de soportes prismáticos o en forma de media luna.

\section{VALORACIONES DE CONJUNTO: EVOLUCIÓN Y VACÍOS DE INVESTIGACIÓN}

Parece oportuno recapitular lo expuesto sobre la secuencia evolutiva de esta práctica en estos otros ambientes mediterráneos como contrapunto a nuestras hipótesis sobre los prismas de origen fenicio y, al mismo tiempo, como medio de contrastación de posibles lazos tecnológicos entre diversas esferas culturales. Sin embargo, esta interpretación que ahora ofrecemos debe enmarcarse en un contexto como el actual, marcado por una fase inicial de la denominada Arqueología de la Producción (Mannoni y Giannichedda 1996) y, dentro de ella, de un análisis moderno de las evidencias relativas a la producción alfarera. Esta situación, que ha evolucionado positivamente en las últimas décadas, ha sido recientemente definida por E. Hasaki precisamente en referencia a la obra de V. Cracolici (2003) sobre los soportes metapontinos:

Kilns and kiln supports have often been missed or misidentified in earlier publications, largely because of a lack of comparanda, but this picture is changing rapidly. [...] In the last two decades, archaeologists have expanded their interest in the working environment of the ancient Mediterranean potter, moving into technological studies with the zeal once reserved for iconography and typology (Hasaki 2007: consulta 25.02.2011).

Por todo ello esta síntesis sólo puede considerarse un avance de un discurso mucho más articulado que habrá de configurarse en los próximos años a partir de la multiplicación de memorias científicas producidas por los numerosos proyectos y excavaciones de alfares en el Mediterráneo.

La situación para la etapa geométrica-orientalizante dista mucho de estar suficientemente dotada de contextos y datos fiables como para establecer un panorama bien cimentado, a partir del cual fuera posible desentrañar los orígenes remotos de la utilización de elementos auxiliares en los hornos griegos o itálicos. En el caso del área etrusca, los datos de Tarquinia y otros centros productores de época arcaica de la región parecen apuntar a la introducción muy temprana (s. VII a.n.e.) de estos elementos entre el instrumental habitual de muchos alfareros de la época, sin que pueda determinarse por el momento la posibilidad de transferencias tecnológicas helenizantes o incluso la posible acción de artesanos o talleres itinerantes propiamente griegos (Nijboer 1998). El paisaje mostrado por las evidencias contemporáneas reunidas por Papadopoulos (2003) para el caso ateniense apunta también a un uso tímido de posibles anillos o cilindros pero, sobre todo, refuerza la introducción temprana de soportes o cuñas macizas en estos primeros momentos, si bien la documentación disponible obliga a ser muy cautos en cuanto a la definición morfo-tipológica de estos utensilios auxiliares. El caso de los Tile Works de Corinto parece ilustrar con mayor contundencia documental la relación de estos prismas, pirámides o paralelepípedos macizos (Merker 2006: 21-22), que en el siglo VI a.n.e. serían objetos habituales usados en la mejora de las condiciones de carga de los hornos destinados fundamentalmente a la cocción de material constructivo. Es esta última cuestión, la habitual relación de estos prismas y pirámides con la fabricación de categorías vasculares de gran formato y, sobre todo, con material constructivo, una de las líneas a desarrollar en los próximos años, a fin de verificar si en realidad se trata de una evidencia sesgada o si, por el contrario, otras producciones comunes o barnizadas utilizaron estos mismos elementos o versiones de ellos para ajustar y apilar las cargas fornáceas.

En su reciente obra sobre los soportes metapontinos, V. Cracolici realizaba también algunas consideraciones 
sobre esta introducción y evolución del uso de todo tipo de soportes y distanciadores en el mundo griego, estableciendo una propuesta secuenciada sobre todo a partir de la documentación magnogreca y siciliota. Este autor considera también los soportes a cuneo y a staffa (grupos VI-VII de su tipología y los más próximos a nuestros tipos $\mathrm{A}$ y $\mathrm{C}$ ) los más antiguos utilizados en las alfarerías helenas, señalando sin embargo que "In età arcaica non è noto l'uso di sostegni per impilaggio di vasi, anche per le classi di maggior pregio, come le ceramiche figurate o a vernice nera" (Cracolici 2003: 109). Este supuesto vendría avalado por la cronología más antigua de los soportes de Himera o de la inexistencia de restos de ningún tipo en el testar arcaico del propio kerameikos de Metaponto, aunque testimonios publicados posteriormente (Corinto, Tarquinia, etc., v. Hasaki 2002, Baratti y Mordeglia 2009, Boitani et al. 2009), han venido a poner en cuarentena la rigidez de estas inferencias, por lo que no puede excluirse un origen arcaico o anterior para la utilización de soportes macizados en ámbito magnogriego-siciliano. La ya citada inscripción votiva de Nikomachos, datada hacia la mitad del s. VI a.n.e. (Cracolici 2003: 128) podría ser otro argumento de interés a favor de esta opción. En cualquier caso, Cracolici también aporta sugerentes ideas respecto a la catalogación de estas series de cuñas y medias lunas como tipos tremendamente versátiles y pertenecientes a "técnicas de difusión universal" básicas en el trabajo alfarero, lo que justificaría la larga perduración de dichas formas -sin sustanciales modificaciones morfométricas- hasta la etapa helenística o incluso posteriores, si bien con un protagonismo cuantitativo cada vez más restringido ante el progresivo ascenso de los distanciadores de anillo vinculados a la producción estandarizada de cerámica barnizada/figurada, en la que cuñas y prismas parece que tuvieron escasa utilidad. En este sentido, resulta interesante la propuesta de Cracolici acerca de que la complejidad y variedad de los soportes/distanciadores parece normalmente proporcional a la propia diversidad de formas y clases cerámicas fabricadas en un taller, constituyendo el progreso de las producciones figuradas (FN/FR) y de barniz negro un posible factor decisivo, primero hacia la atomización de las morfologías de soportes y, más tarde, hacia el extremo opuesto con la estandarización y desecho de las formas más complejas. Aunque al margen de la discusión planteada en este trabajo en relación a las cuñas y soportes de otros grupos, resulta interesante observar cómo, siguiendo el ejemplo de Metaponto, parece poder advertirse una primera fase de cierta experimentación antieconómica en la segunda mitad del s. V a.n.e. (con una insostenible diversidad de formas y módulos), rápidamente extendida a Grecia continental, Magna Grecia y Sicilia que, durante el s. IV a.n.e. evolucionaría a una situación de simplificación y estandarización en la que continuarían en producción los tipos más duraderos y versátiles que sirviesen para potenciar la creciente producción masiva de vajillas de barniz negro (Cracolici 2003: 111-112). En este contexto, la perduración de formas a cuneo y a staffa hasta la etapa romano-republicana o imperial parece secundar esta progresiva preocupación por el ahorro de costes en la fabricación de soportes y distanciadores, si bien las evidencias disponibles no permiten advertir si también en estos tipos se realizaron ajustes tipológicos como en el caso de anillos, campanas o cilindros.

Otro caso paradigmático que podemos añadir a los ya referidos lo encontramos en la antigua ciudad lacial de Signia, en cuyo territorio periurbano se ubicó una $f$ glina activa durante el último tercio del s. IV a.n.e. y los inicios del III a.n.e., relacionándose la producción de esta oficina con el nutrido conjunto de ofrendas votivas documentadas en el templo de Juno situado en la acrópolis de la ciudad. Entre estas ofrendas ha sido destacada la presencia de un distanciador ad anello que portaba una inscripción incisa precocción (L.FICVL. FEC) que se ha interpretado como un depósito ritual debido a un figulus, subrayando probablemente aún más la actividad cultual con la producción alfarera en el territorium de la ciudad (Stanco 1988: 17, tav. 20, Cifarelli 2003: 181, nota 445).

En efecto, los contextos alfareros itálicos de época helenística y romano-republicana, especialmente los del área campana, centroitálica (Di Giuseppe 2005) y etrusca, parecen ser elocuentes sobre el triunfo de sencillas versiones de distanciadores ad anello en los talleres de fabricación de barniz negro o incluso sigillata, pero de igual forma testimonian la supervivencia en toda la zona de cuñas y elementos macizos de diverso porte y morfología igualmente usados en los hornos de esta fase. La escasez y fragmentariedad de los datos no permite por el momento establecer si, en estas fases más recientes, la utilización de cuñas o prismas habría estado exclusivamente orientada a producciones de gran peso o volumen, como en etapas precedentes, o si, por el contrario, habrían sido herramientas más polivalentes empleadas también al menos puntualmente en la cocción de otras series más delicadas.

Cabe preguntarse en este punto, ante una perspectiva cada vez más clarificada de la problemática de las esferas tecnológicas griega e itálica, qué información poseemos sobre estas mismas cuestiones en el seno de 
los talleres alfareros fenicio-púnicos, tanto en el área matriz próximo-oriental como en las colonias y asentamientos distribuidos por las costas africanas, maltesas, sicilianas o sardas. Lo cierto es que esta problemática del uso de distanciadores/soportes/cuñas parece haber pasado hasta el momento prácticamente desapercibida en el ámbito del estudio de estos entornos artesanales semitas, tanto en Oriente como en Occidente y, por ahora, apenas son visibles evidencias de ello en la bibliografía disponible ni se ha alertado sobre su ausencia en el debate tecnológico. La publicación de complejos alfareros de importancia en el área fenicia oriental como Sarepta (Pritchard 1975: 71-84, Anderson 1987: 41-66), Deir el-Balah o Ekron (Killebrew 1996) no han comportado trabajos en profundidad sobre los procesos productivos -y su instrumental asociado-, habiéndose puesto el acento tradicionalmente en aspectos como las producciones, la tipología fornácea o las técnicas constructivas (Delcroix y Hout 1972 o Falsone 1981, con amplia bibliografía anterior).

A pesar de la escasez de estudios específicos y evidencias directas, el alto nivel de desarrollo técnico de la industria alfarera cananea desde la Edad del Bronce y su especialización en la producción de envases de cierto volumen (especialmente ánforas de transporte comercial) nos hace sospechar que el posible origen remoto de los prismas de nuestro Tipo A, precursores en ámbito peninsular de estas técnicas, podría encontrarse en los usos habituales de los talleres orientales precoloniales. Un testimonio que parece confirmar plenamente estas intuiciones ha sido dado a conocer recientemente a partir del estudio del importante sector alfarero del dunnu asirio de Tell Sabi Abyad (Siria), cuya actividad parece que se extendió fundamentalmente en el Bronce Final entre los siglos XIV/XII a.n.e. y que contaba con un gran número de hornos y estructuras de talleres muy evolucionadas. Entre el utillaje usado por los alfareros, han podido localizarse en las inmediaciones de algunos de los hornos piezas prismáticas, similares al Tipo A o incluso al B, que han sido relacionadas por sus excavadores, tras un minucioso análisis tecnológico, con las operaciones de carga de las piezas a cocer en los hornos (Duistermaat 2007: 701, fig. V.7). Probablemente este hallazgo es apenas un primer destello de un océano de testimonios del mismo tipo que aguardan aún a ser identificados y publicados en toda la zona próximooriental, pero resulta casi definitivo en relación a demostrar que esta técnica de optimización de la carga de los hornos comparte una misma raíz oriental con los hornos de doble cámara, el adobe plano-convexo o el torno de alfarero.
Las evidencias vinculadas a una posible difusión de estos elementos desde Oriente a las colonias del Mediterráneo central y occidental son igualmente escasas (más allá de los datos ya comentados relativos a Iberia), adoleciendo la publicación de los talleres de estas áreas de estudios monográficos de sus kiln furniture. Resultan a este respecto sintomáticos los casos de alfarerías de Cartago de cronología arcaica (Vegas 1998) y tardopúnica (Gauckler 1915), las diversas áreas artesanales y hornos excavados en Mozia (Falsone 1981), los testimonios de producción cerámica de diversa magnitud recuperados en la ciudad de Kerkouane (una reciente síntesis en Fantar 2010) o un testar localizado en Olbia (Sanciu 1995), centros manufactureros en los que no se han publicado restos relativos al uso de soportes o distanciadores -o cualquier otro tipo de instrumental alfarero- desde época arcaica. Lo cierto es que casi en ninguno de estos casos, bien por tratarse de excavaciones reducidas o muy antiguas, se ha procedido a una divulgación detallada de los materiales asociados a los hornos e instalaciones de taller, lo que podría haber desembocado en esta invisibilidad actual de los elementos auxiliares de las labores productivas. En el caso del alfar tardoarcaico (datado entre fines del VII e inicios del VI a.n.e.) de Cartago localizado en el área del Cardo IX, algunos elementos clasificados como braseros, de morfología acilindrada y con perforaciones de aireación (Vegas 1998: 162-164, fig. 7, 76-78), podrían plantear algunas dudas sobre su posible utilización como distanciadores de horno, si bien la presencia en alguno de los ejemplares de mamelones de suspensión (para el apoyo de elementos en su parte superior) parece acomodarse más a la interpretación original como parte del elenco de elementos de uso culinario cartaginés del momento. A estos casos centromediterráneos podríamos quizá añadir, partiendo de lo dado a conocer de sus alfares periurbanos y rurales, el caso de Ibiza (Ramón 1991, 1995, 1997 y 1998), ya que ni en los talleres de época púnica ni en los de época helenística parecen haberse documentado elementos prismáticos, aunque sí distanciadores para la cocción de cerámicas barnizadas. En este sentido, merece la pena recordar la opinión expresada por J. P. Morel -basada fundamentalmente en los testimonios de Byrsa-, respecto a las características técnicas de la cocción de los barnices propios de los talleres púnicos, señalando este autor que la aparición frecuente de huellas de apilamiento en la parte interna de los vasos de esta procedencia sería una prueba evidente de que los ceramistas púnicos no habrían utilizado distanciadores para optimizar las cargas y acabados de las piezas (Morel 1982: 52-53). Para el 
área extremo-occidental, otro tanto podemos por el momento sostener para el paradigmático caso de Kouass, donde en el reestudio reciente de los materiales tampoco parecen haberse localizado restos evidentes que indiquen el uso de útiles auxiliares (Kbiri Alaoui 2007). En cualquier caso, el panorama actual según la información publicada, parece delinear un auténtico vacío que no permite asegurar o descartar ninguna hipótesis de forma tajante, configurándose como una línea prioritaria el estudio de la cerámica fenicio-púnica colonial y de sus orígenes técnicos.

Sin embargo, en relación a un centro productor de época helenística de la ciudad siciliana de Solunto, plenamente inserta en la compleja dinámica de interacción cultural y bélica/territorial desarrollada por cartagineses y griegos en la isla, ha podido ser atestiguado el uso de distanciadores de tipo helenizante en talleres de la órbita púnica. Se trata de un complejo industrial de cierta importancia documentado en el área de Monte Catalfano (Greco 2000) en el que parece que fueron usados distanciadores ad anello (grupo III de Metaponto) en relación con la fabricación de cerámicas de barniz negro (Cracolici 2003: 24, fig. 4, nota 43). Esta evidencia parece poner sobre el tapete la existencia de procesos de interacción y transferencia tecnológica alfarera en el área siciliana, participando posiblemente otros centros púnicos de la parte occidental de la isla de estas mismas transformaciones. Se abre así la posibilidad de que fuera esta zona un laboratorio óptimo para la gestación de nuevos modelos productivos híbridos, así como para la difusión indirecta hacia otras zonas del Mediterráneo occidental de técnicas procedentes de las alfarerías magnogrecas, lo que a nuestro juicio subraya aún más la necesidad de atender más detalladamente este tipo de investigaciones en otras urbes cartaginesas o extremo-occidentales.

El caso particular de Solunto enfatiza este posible mestizaje tecnológico entre el mundo púnico y el mundo griego, ampliable a la relación con otras sociedades de territorios orientalizados y/o helenizados ampliamente, receptores de forma directa o indirecta de estas mismas tecnologías. Los cauces y profundidades de estas interacciones, en un mundo mediterráneo protohistórico con circuitos comerciales y de comunicación internacionalizados y una alta movilidad de poblaciones (especialmente en los primeros siglos del primer milenio a.n.e.), son imposibles de descifrar con la documentación fragmentaria actual, planteando las conexiones formales entre prismas (Tipo A) y distanciadores a tacco o a cuneo, sugerentes vías de investigación futuras. La primera etapa de uso de los prismas en los alfares peninsulares en época arcaica temprana (s. VIII a.n.e.) determina una llegada casi inmediata a los ambientes coloniales orientalizantes de tecnologías alfareras desarrolladas, usándose aparentemente de forma generalizada los pequeños prismas de nuestro Tipo A. En ámbito griego e itálico este fenómeno es más complejo de leer, pues las evidencias de talleres tanto en Grecia continental como en las nuevas colonias no son por ahora tan explícitas. No obstante, testimonios de formas troncopiramidales o prismas cuadrangulares como los vistos en Atenas, Corinto, Tarquinia o Entella (en contextos de los siglos VII y VI a.n.e., sobre todo) parecen apuntar a un peso en esta fase inicial de técnicas similares a las usadas por los fenicios. Esto plantearía la ineludible pregunta sobre una posible influencia cananea en la producción cerámica griega de estos momentos, en cuestiones como este uso generalizado de cuñas y elementos macizos, si bien no hay que olvidar que pueden incluirse en la categoría de "tipos universales" multifuncionales y de larga perduración. Del mismo modo, el uso generalizado de soportes a staffa en el área magnogreca e itálica desde al menos la etapa clásica (perdurando al menos hasta la fase tardorrepublicana), posiblemente también en el área egea, plantea no menos preguntas sobre su relación con la gestación de los prismas semitizantes de nuestro Tipo B y sobre todo del grupo C, cuyos ejemplares responden sorprendentemente en forma y dimensiones a los soportes/cuñas griegos. La extensión del uso de elementos del Tipo $\mathrm{C}$ desde la actual Extremadura hasta el noreste ibérico, con una amplia dispersión en el área levantina ibérica (alcanzando una difusión aparentemente mucho más importante que los tipos A-B), no permite desechar una posible influencia helena en la generación de tradiciones alfareras ibéricas mixtas -con una base púnica- o la recepción indirecta (bien por contacto con el mundo cartaginés o posteriormente con Roma). Por ahora, ante la falta de evidencias concluyentes en uno u otro sentido, parece factible pensar en un solapamiento cultural y una multiplicidad de orígenes técnicos para el uso de los soportes semilunares, basados quizá en un sustrato orientalizante matizado en momentos más recientes por la recepción de fuertes influjos griegos (la propia tipología vascular ibérica parece elocuente) y romanos.

Finalmente, debemos remarcar una última idea derivada de este repaso a las evidencias del arco mediterráneo en relación a los datos peninsulares: destaca con fuerza el aparente contraste entre esta ausencia de testimonios en casi toda el "área punicizante" centromediterránea y la presencia, en cierto modo exuberante, 
de prismas en alfarerías fenicio-púnicas, turdetanas o ibéricas de la Península Ibérica, situación a la que por ahora no podemos encontrar una explicación definitiva sin correr el riesgo de usar argumentos ex silentio. Podría tratarse de cuestiones simples como la existencia de diversas tradiciones alfareras transplantadas a Occidente que posteriormente se desarrollarían de manera más o menos independiente, siendo la importancia de la producción malacitana de época arcaica la principal responsable de la pronta expansión de los prismas a diversas zonas del ámbito indígena. Sin embargo, las causas de la evolución formal de aquellos en momentos tardoclásicos/helenísticos hacia los tipos B/C no se encuentran tan definidas y su relación con cuñas y soportes semilunares usados en alfares magnogrecos no permiten descartar la existencia de influencias helenizantes, especialmente acusadas en la fachada ibérica levantina, para la configuración de nuestro grupo C. Como ya señalamos, creemos que se trata de vías de investigación abiertas y con enormes posibilidades de desarrollo que será positivo desarrollar a corto/medio plazo dada su evidente utilidad arqueo-histórica.

\section{DISCUSIÓN}

\subsection{Origen costero y vías de penetración en el mundo indígena}

La cuestión fundamental tratada en estas páginas ha sido la del origen y expansión durante el primer milenio a.n.e. de la tecnología alfarera relacionada con el uso de prismas cerámicos en suelo peninsular, pregunta a la que la escasa evidencia disponible en las metrópolis fenicias orientales no permite contestar de forma rotunda sino más bien esbozar una sospecha de un origen sirio-cananeo. En cualquier caso, resulta evidente que la implantación de estos prismas en los alfares coloniales -posiblemente desde una etapa inicial de la propia erección de los asentamientos coloniales y de la generación de los primeros circuitos comerciales en los albores del milenio- formó parte de un desarrollo tecnológico mucho más complejo que involucró la participación de otros ingredientes como artesanos altamente especializados y organizados, estructuras de taller (con balsas de decantación, tornos, áreas dedicadas a la pintura/decoración, a la fabricación de desgrasantes y pigmentos, etc.) y hornos de tradición oriental dotados de doble cámara y un avanzado control del consumo de combustible y de los tiempos y temperaturas de cocción. Todos estos elementos combinados parece que fueron rápidamente reproducidos en al menos una parte de los asentamientos coloniales del Extremo Occidente desde momentos tempranos de su creación en relación al autoabastecimiento y las funciones comerciales, conformando en algún caso auténticas aglomeraciones artesanales al modo de las desarrolladas en las metrópolis orientales. Estos talleres coloniales, en los que la fabricación de ánforas debió tener siempre un peso específico, continuaron con una intensa actividad durante toda la etapa arcaica, destacando la vivacidad y difusión de las producciones malacitanas (franja que como hemos señalado parece que se configura como la principal plataforma de entrada y uso de los prismas cerámicos).

La presencia de los prismas en estas alfarerías fenicias costeras no plantea por tanto dificultades de interpretación y sólo resta por clarificar el hecho de la aparente tradición industrial que parece delimitar la ausencia de estos elementos en Gadir (pendiente también de la propia localización de alfares arcaicos en la bahía gaditana), hecho diferencial reproducido en toda la etapa postcolonial cuyo verdadero calado histórico está aún por dimensionar completamente. Sin embargo, los mecanismos precisos de transmisión de este "paquete tecnológico alfarero", incluyendo los prismas, desde estas colonias fenicias hasta implantarlos y hacerlos propios de los núcleos tartésicos sí que suponen un escollo complicado para explicar esta difusión. En efecto, desconocemos el modelo establecido en los contactos entre los fenicios occidentales y las comunidades tartésicas para la transmisión de estas técnicas orientales al mundo indígena. Un proceso que debió comportar la participación directa de artesanos fenicios en el adiestramiento de alfareros tartesios pero también en la construcción de hornos y tornos y en la compleja explotación de canteras de arcillas y su posterior procesamiento. Si esta interacción se realizó en el ámbito de intercambios comerciales, de prestigio o de una forma bidireccional (a través también de la presencia de indígenas en los propios talleres coloniales) no puede determinarse, pero sí resulta de interés resaltar que esta transferencia sembraba uno de los puntales germinales del fin del intercambio desigual, aportando al mundo tartésico-ibérico una herramienta vital para el desarrollo de sus propios circuitos y envases comerciales, y fomentando al mismo tiempo la plástica o la creación de gremios artesanales y de un mercado interior cada vez más potente y autosuficiente. Los testimonios analizados correspondientes a los siglos VII y VI a.n.e., entre los que encontramos abundantes hornos al sur del Guadalquivir o en el área murciana, son elocuentes respecto 
a una rápida adopción de todo el pack alfarero, participando los prismas del Tipo A en este proceso seguramente en la generalidad de casos (lo que indica un aprendizaje de las técnicas muy profundo que habría incluido la optimización de los procesos de carga y cocción). Partiendo del probable protagonismo del área de Málaga en la introducción de los prismas en suelo peninsular, la evidencia disponible invita a situar a los fenicios de la costa mediterránea como protagonistas de estos circuitos de interacción con las comunidades indígenas durante gran parte de la etapa arcaica, supuesto que será necesario verificar a partir de otras líneas paralelas de análisis en el futuro.

La creación y difusión de los prismas más evolucionados, los incluidos en el Tipo B o las diversas variantes de nuestro Tipo $\mathrm{C}$, parecen apartarse de estos complejos procesos de interacción y asimilación cultural y económica de época arcaica plena. En su conformación tipológica las alfarerías ibéricas o turdetanas habrían participado ya de partida en un plano de igualdad técnica que no permite situar por el momento con precisión los cauces de creación/introducción de estos modelos, sin descartar un protagonismo del propio mundo ibérico en la cuestión. Los hallazgos más recientes de Torrevieja o los prismas evolucionados localizados en horizontes antiguos de Los Caños o Arroyo Hondo podrían, sin embargo, sugerir una gestación de este uso de formas curvadas o plenamente semilunares en el suroeste andaluz, y una difusión algo más tardía hacia Levante o el Noreste de Iberia. En cualquier caso, un vistazo al plano de dispersión tardía que presentamos ahora, parece evidenciar más que unas vías de difusión anómalas, la existencia de verdaderos vacíos de investigación en amplias zonas de la península, lo que condiciona actualmente de forma notable las posibilidades de lectura de estos procesos. Consideramos que los focos localizados en el área murciana, alicantina, valenciana o barcelonesa corresponden probablemente a la punta del iceberg de un fenómeno mucho más amplio y capilarizado, del mismo modo que la exigua muestra del mediodía peninsular no parece ser verdaderamente representativa y sí reflejo de una escasa atención recibida hasta ahora por los alfares turdetanos, bastetanos u oretanos. El papel de terceros (cartagineses o romanos, especialmente) en este crecimiento exponencial del uso de prismas de Tipo $\mathrm{C}$ en época helenística queda también, por ahora, en suspenso hasta contar con evidencias más numerosas y detalladas, lo que añade un grado más de complejidad a la lectura del plano disponible.

\subsection{Cuestiones de funcionalidad}

Una de las principales preguntas que nos planteábamos al iniciar la investigación sobre los prismas era si éstos podían ser considerados como hitos relacionados exclusivamente con las labores alfareras o si, por el contrario, habían constituido parte de un utillaje cotidiano polifuncional también usado en otros ambientes. Los testimonios que hemos ido desgranando en detalle en los apartados precedentes permiten confirmar que gran parte de los hallazgos de los diversos tipos de prismas y soportes semilunares se relacionan con hornos o talleres alfareros o se documentaron en testares. Por consiguiente, esta circunstancia parece apoyar un uso de estos elementos prioritariamente vinculado a labores artesanales ligadas a la producción cerámica, si bien no puede descartarse completamente que los prismas interviniesen en otras tareas desligadas de la actividad alfarera. Unas actividades alternativas por el momento difíciles de definir, verosímilmente ejerciendo una función de cuña o soporte análoga a la de uso industrial, pero posiblemente aplicados al almacenaje u otras labores cotidianas. Por tanto, por el momento las evidencias disponibles como marco de referencia no permiten plantear una correlación exclusiva prisma-alfar, aunque sí permiten esbozar que es muy probable que existiesen actividades productivas en los yacimientos en los que se han detectado este tipo de piezas.

En este marco aún deficientemente definido sobre la dimensión de los prismas como ítem alfarero singular hay que situar también la problemática relacionada con el uso específico de estos elementos en las diversas labores manufactureras. Los hallazgos peninsulares realizados en contextos alfareros no han solucionado por el momento esta cuestión, documentándose en todos los extremos de la secuencia productiva: en relación directa con áreas de secado, de taller, con los propios hornos o con otras zonas no definidas funcionalmente de las alfarerías. Los paralelos aportados procedentes del mundo griego e itálico y las características físicas de parte de los hallazgos, que incluyen piezas con defectos por cocciones reiteradas o desechadas en testares, parecen indicar un uso prioritario en las tareas de apilamiento, ajuste y soporte de las cargas de los hornos antes de la cocción, tal y como ya se había propuesto para el caso del Cerro del Villar (Aubet et al. 1999: 289-290). Sin embargo, no puede excluirse un uso puntual o complementario relacionado con otros pasos del trabajo en las alfarerías, tales como el posicionamiento ordenado de las piezas en el secado previo a la cocción o el almacenaje anterior a la distribución 
de los productos acabados. Sólo nuevas intervenciones en complejos productores, desarrolladas con una metodología de rastreo microespacial de estas evidencias, y una publicación minuciosa de las evidencias ya disponibles permitirán arrojar nueva luz sobre esta cuestión, necesitada por el momento de un carácter más explícito de las evidencias arqueológicas.

En definitiva, podemos concluir respecto a la cuestión de la funcionalidad y empleo concreto de las diversas categorías de prismas que partimos de la consideración general de estas piezas como parte del instrumental alfarero básico, si bien con la cautela derivada de su posible implicación en otras tareas $\mathrm{y}$, por otro lado, que el papel concreto dentro de los talleres queda por el momento abierto a nuevos datos, aunque por el momento su relación con las tareas de carga/cocción parece la opción más probable.

\subsection{Perspectivas}

Los prismas de uso alfarero tratados en estas páginas, así como otros elementos auxiliares (soportes/ distanciadores) sobre los que también se ha incidido, constituyen un grupo de argumentos arqueológicos de enorme interés para la identificación y caracterización de áreas con actividad alfarera. Al mismo tiempo se revelan como herramientas imprescindibles para acercarnos a los procesos de manufactura desarrollados en el seno de dichos talleres. Aunque no siempre de forma inequívoca, ya que en ocasiones los prismas y soportes pudieron ser usados en otro tipo de contextos, parece que generalmente estos ítems pueden considerarse como claros indicadores sobre la existencia de oficinas cerámicas en las proximidades de un yacimiento, lo que parece dotar de un elevado valor a estas piezas generalmente de escasa plasticidad y normalmente no publicadas o minusvaloradas. Por ello, consideramos que los datos expuestos, condicionados por esta escasa atención recibida hasta el momento, deben poner de relieve la enorme potencialidad del estudio de este tipo de elementos auxiliares como evidencia arqueológica funcional y cronológica y, de igual modo, como fuente histórica, al constituir un ingrediente esencial para la lectura de procesos económicos de alta complejidad.

\section{CONCLUSIONES}

El modesto objetivo de nuestra propuesta tipológica y de la perspectiva mediterránea que hemos intentado sintetizar aquí, no ha sido otro que el hacer visibles no los prismas (bien conocidos en la bibliografía reciente), sino su valor como herramienta de investigación y el planteamiento de algunas preguntas sobre sus orígenes/evolución/función y la creación de un marco de referencia común que recogiese la dispersa información publicada. Queda a partir de ahora un largo camino por recorrer en el estudio de los prismas de origen fenicio, con un importante déficit de atención precisamente en el análisis del kiln furniture de los talleres fenicio-púnicos extra-peninsulares, pero con unas perspectivas muy positivas en este sentido que a buen seguro han de matizar y ampliar los supuestos esbozados ahora. No será desde luego una de las tareas menores a acometer en los próximos años, como tampoco lo será la creación de vías de análisis de las ya esbozadas conexiones crono-tipológicas entre los prismas de origen fenicio y algunas formas de soportes y cuñas muy populares entre los artesanos griegos e itálicos, relaciones aún por evaluar en toda su complejidad y extensión a partir de un registro arqueológico más amplio y contextualizado.

\section{AGRADECIMIENTOS}

El interés de los autores por los soportes/separadores cerámicos de tipo prismático se generó como resultado de las excavaciones periódicas en el yacimiento de Torrevieja (Villamartín, Cádiz). Dichas intervenciones arqueológicas han contado con el apoyo del Excmo. Ayuntamiento de Villamartín. Este trabajo se ha desarrollado en el ámbito de actuación del Proyecto de Excelencia Amphorae ex Hispania (HAR2011-28244), dirigido por el Prof. Dr. Ramón Járrega Domínguez (amphorae.icac.net). Los redactores del artículo son miembros del Grupo de Investigación PAI HUM-440 de la Universidad de Cádiz "El Círculo del Estrecho de Gibraltar en la Historia. Estudio arqueológico y arqueométrico de las sociedades desde la Prehistoria a la Antigüedad Tardía".

\section{BIBLIOGRAFÍA}

Adamesteanu, D. (1954): "Uno scarico di fornace ellenistica da Gela”. Archeologia Classica VI: 129-132.

Adamesteanu, D. (1970): "L'attività archeologica in Basilicata”, en Atti del IX Convegno Internazionale di Studi sulla Magna Grecia, pp. 215-237. Nápoles, Arte Tipografica. 
Adamesteanu, D. (1974): La Basilicata antica. Storia e monumenti. Cava dei Tirreni, Di Mauro Editore.

Aguayo de Hoyos, P. (2001): "Estructuras indígenas, comercio y comerciantes en la época de la colonización fenicia en Málaga (VIII-VI a.C)", en F. Wulff, G. Cruz y C. Martínez (eds.), Comercio y comerciantes en la Historia Antigua de Málaga (Siglo VIII a. C. año 711 d. C.), Actas II Congreso de Historia Antigua de Málaga, pp. 69-97. Málaga, Centro de Ediciones Diputación Málaga.

Aguayo, P. y Carrilero, M. (1996): "Las intervenciones arqueológicas en la zona de Ronda", en I Congreso de Historia Antigua de Málaga y su Provincia, pp. 353-372. Málaga, Arguval.

Aguayo, P., Castilla, J. y Padial, B. (1992): “Excavación de urgencia en el casco antiguo de Ronda. Calle Armiñán no 39, 41, 43 y Aurora n 16. 1989". Anuario Arqueológico de Andalucía 1990/III: 339-342.

Aguayo, P.; Garrido, O. y Padial, B. (1995): “Una ruta terrestre alternativa al paso del Estrecho en época orientalizante: constatación arqueológica”, en E. Ripoll y M. F. Ladero (eds.), Actas del II Congreso Internacional 'El Estrecho de Gibraltar' II. Arqueología Clásica e Historia Antigua, pp. 85-97. Madrid, UNED.

Alfaro Arregui, M. (1995): “El poblado ibérico de El Amarejo (Bonete, Albacete)", en J. Blánquez (ed.), El mundo ibérico: una nueva imagen en los albores del año 2000, pp. 231-237. Toledo. Junta de Comunidades, Castilla-La Mancha.

Anderson, W.P. (1987): "The kilns and workshops of Sarepta (Sarafand, Lebanon): Remnants of a phoenician ceramic industry". Berytus XXXV: 41-66.

Aquilué, X. (dir.) (1999): Intervencions arqueològiques a Sant Martí d'Empúries (1994-1996). De l'assentament precolonial a l'Empúries actual. Monografies Emporitanes 9. Gerona, MAC.

Aquilué, X.; Castanyer, P.; Santos, M. y Tremoleda, J. (2001): "Les ceràmiques gregues arcaiques de la Palaià Polis d'Empòrion", en P. Cabrera y M. Santos (coords.), Ceràmiques jònies d'època arcaica: centres de producció i comercialització al Mediterrani Occidental. Monografies Emporitanes 11, pp. 285-338. Barcelona.

Arancibia Román, A. y Escalante Aguilar, M.M. (2006): "La Málaga fenicio-púnica a la luz de los últimos hallazgos". Mainake XXVIII: 333-360.

Arancibia Román, A. y Escalante Aguilar, M.M. (2010): "Aportaciones a la arqueología urbana de Málaga, de la Málaga fenicia a la Málaga bizantina a través de los resultados de la excavación de c/ Cister 3-San Agustín 4". Anuario Arqueológico de Andalucia/2006. Provincia de Málaga: 36363656. http://www.juntadeandalucia/cultura/publico/ BBCC/Anuario_2006/Malaga.pdf [20.02.2011]

Arribas, A. y Arteaga, O. (1975): El yacimiento fenicio de la desembocadura del río Guadalhorce (Málaga). Cuadernos de Prehistoria de la Universidad de Granada. Serie Monográfica n 2 . Granada, Universidad de Granada.

Arthur, P. (1986): "Problems of the urbanization of Pompeii: excavations 1980-1981". Antiquaries Journal LXVI (1): 29-44.

Aubet Semmler, M.E.; Carmona, P.; Curia, E.; Delgado, A.; Fernández, A. y Párraga, M. (1999): Cerro del Villar I. El asentamiento fenicio en la desembocadura del Guadalhorce y su interacción con el hinterland. Monografías de la Junta de Andalucía. Sevilla, Junta de Andalucía.

Baratti, G. y Mordeglia, L. (2009): “Un'officina per la cottura di tegole a Tarquinia in età orientalizzante", en I mestieri del fuoco. Officine e impianti artigianali nell'Italia preromana. Officina Etruscologia 1: 83-99. Roma, Officina Edizioni.

Barceló, J.A.; Delgado, A.; Fernández, A. y Párraga, M. (1995): "El área de producción alfarera del Cerro del Villar (Guadalhorce, Málaga)". Rivista di Studi Fenici XXIII (2): 147-183.

Barra Bagnasco, M. (1976): "Problema di urbanistica locrese", en Atti del XVI Convegno Internazionale di Studi sulla Magna Grecia: 375-408. Nápoles, Arte Tipografica.

Barra Bagnasco, M. (1984): "Documenti di architettura minore in età ellenistica a Locri Epizefiri", en A. Adriani, N. Bonacasa y A. Di Vita (eds.), Alessandria e il mondo ellenistico-romano. Studi in memoria di Achille Adriani, III, pp. 498-519. Roma, L'Erma di Bretschneider.

Belén, M.; Anglada, R.; Escacena, J.L.; Jiménez, A.; Lineros, R. y Rodríguez, I. (1997): Arqueología en Carmona (Sevilla). Excavaciones en la Casa-Palacio del Marqués de Saltillo. Arqueología Monografías. Sevilla, Junta de Andalucía.

Belén, M. y Escacena, J.L. (1999): “Testimonios religiosos de la presencia fenicia en Andalucía Occidental". Spal 6: 103-131. http://dx.doi.org/10.12795/ spal.1997.i6.07

Bergamini, M. y Gaggiotti, M. (2011): "Manufatti e strumenti funzionali alla lavorazione dell'argilla e alla cottura”, en M. Bergamini (ed.), Scoppieto II. I materiali, pp. 343-377. Florencia, All'Insegna del Giglio. 
Biocco, E. y Silvestrini, M. (2008): "Popolamento e dinamiche insediative", en T. Sabbatini y M. Silvestrini (eds.), Potere e splendore: gli antichi Piceni a Matelica, pp. 27-39. Roma, L'Erma di Bretschneider.

Blondé, F.; Perreault, J.Y. y Péristéri, C. (1992): “L’atelier de potier archaïque de Phari", en F. Blondé y J.Y. Perreault (eds.), Les ateliers de potiers dans le monde grec aux époques géométrique, archaïque et classique. Actes de la Table Ronde organisée par l'Ecole Française d'Archéologie d'Athènes, Bulletin de Correspondance Hellénique, Supplément 23, pp. 11-40. Atenas (1987), Atenas.

Boitani, F.; Neri, S. y Biagi, F. (2009): 'Novità dall'impianto produttivo della prima età del Ferro di VeioCampetti". I mestieri del fuoco. Officine e impianti artigianali nell'Italia preromana, Officina Etruscologia 1, pp. 23-42. Roma, Officina Edizioni.

Bonet Rosado, H. (1995): El Tossal de Sant Miquel de Llíria. La antigua Edeta y su territorio. Valencia, Museo de Prehistoria de Valencia.

Brecciaroli Taborelli, L. (1998): “L’officina cerámica di Aesis (III sec. a.C.-I sec d.C.)". Notizie degli Scavi di Antichità, suplem. IX, VII-VIII, pp. 5-250.

Broncano Rodríguez, S. (1989): El depósito votivo ibérico de El Amarejo, Bonete (Albacete). Excavaciones Arqueológicas en España 158. Madrid, Ministerio de Cultura.

Calzolari, M. (1992): “Bondeno, loc. Barchessa e Zoccolino. Tracce di insediamenti", en M. Calzolari y L. Malnati (eds.), Gli Etruschi nella Bassa modenese. Nuove scoperte e prespettive di ricerca in un settore dell'Etruria padana, pp. 183-205. San Felice sul Panaro (Módena), Gruppo Studi Bassa Modenese.

Castaño Aguilar, J.M. (Dir.) (2005): Ronda: la ciudad. Carta Arqueológica Municipal. Sevilla, Junta de Andalucía.

Castoldi, M. (2008): “Oltre la chora. Nuove indagini archeologiche nell'entroterra di Metaponto", en G. Zanetto, S. Martinelli y M. Ornaghi (eds.), Vestigia antiquitatis, Atti dei Seminari del Dipartimento di Scienze dell'Antichità. Quaderni di Acme 102: 143160. Milán, Università degli Studi di Milano.

Castoldi, M. (coord) (2009): Oltre la chora. Ricognizioni archeologiche e scavi nel Metapontino (MT), tra Pisticci e Ferrandina, http://users.unimi.it/magnagrecia [15.01.2011].

Cavassa, L. (2009): "La production de céramique commune à Pompéi. Un four de potier dans l'insula $5 \mathrm{de}$ la regio I" en M. Pasqualini (dir), Les céramiques communes d'Italie et de Narbonnaise. Structures de production, typologies et contextes inédits (IIe s. av. J.-C.-IIIe s. apr. J-C.). Collection du Centre Jean Bérard 30: 95-104. Nápoles, CNRS.

Chic, G. y García, E. (2004): “Alfares y producciones cerámicas en la provincia de Sevilla: balance y perspectivas”, en D. Bernal y L. Lagóstena (eds.), Actas del Congreso Internacional, Figlinae Baeticae. Talleres alfareros y producciones cerámicas en la Bética romana (ss. II a.C.-VII d.C.). BAR International Series 1266, pp. 279-347. Oxford, Hadrian Books.

Ciacci, A.; Comini, A.; Gliozzo, E.; Memmi Turbanti, I. y Moroni, A. (2009): "Le fornaci del Trebbio (Sansepolcro, AR): aspetti tecnologici”. I mestieri del fuoco. Officine e impianti artigianali nell'Italia preromana. Officina Etruscologia 1, pp. 61-82. Roma, Officina Edizioni.

Cifarelli, F.M. (2003): Il tempio di Giunone Moneta sull'acropoli di Segni. Storia, topografia e decorazione architettonica. Roma, L'Erma di Bretschneider.

Contreras, F.; Carrión, F. y Jabaloy, E. (1983): “Un horno alfarero protohistórico en el Cerro de los Infantes (Pinos Puente, Granada)", en XVI Congreso Nacional de Arqueología, pp. 533-535. Zaragoza, Seminario de Arqueología, Universidad de Zaragoza.

Cracolici, V. (2003): I Sostegni di Fornace dal Kerameikos di Metaponto. Beni Archeologici-Conoscenza e Tecnologie. Quaderno 3. Bari, Edipuglia.

Cuomo di Caprio, N. (1974): "Fornaci per ceramica a Locri”. Klearchos LXI-LXIV: 43-65.

Cuomo di Caprio, N. (2007): Ceramica in Archeologia. 2: Antiche tecniche di lavorazione e moderni metodi di indagine. Studia Archaeologica 144. Roma, L'Erma di Bretschneider.

D’Agostino, B. (1972): “Appunti sulla funzione dell'artigianato in Magna Grecia dall'VIII al VI sec. a.C.", Atti del XII Convegno Internazionale di Studi sulla Magna Grecia, pp. 207-236. Nápoles, Arte Tipografica.

D’Andria, F. (1975): "Scavi nella zona del Kerameikos". Notizie degli Scavi, Suppl. XXIX, pp. 355-452.

De Miro, E. (1963): “Agrigento: scavi nell'area a sud del tempio di Giove". Monumenti Antichi. Serie monografica e miscellanea, XLVI, pp. 81-198. Roma, Accademia Nazionale dei Lincei.

De Stefano, A. (2008): “Un contesto ceramico di età repubblicana e primo/medio imperiale dall'area delle due domus". Ordona. Ricerche archeologiche a Herdonia, X(I): 45-144. Bari, Edipuglia.

Delcroix, G. y Hout, J.L. (1972): "Les fours dits de potiers dans 1'Orient Ancient”. Syria XLIX: 35-95. 
Delgado Hervás, A. (2011): "La producción de cerámica fenicia en el extremo occidente: Hornos de alfar, talleres e industrias domésticas en los enclaves coloniales de la Andalucía mediterránea (Siglos VIII-VI. a. C.)", en B. Costa y J.H. Fernández (eds.), Yõserim: la producción alfarera fenicio-púnica en Occidente. Treballs del Museu Arqueologic d'Eivissa i Formentera 66, pp. 9-48. Ibiza, Museo Arqueológico de Ibiza y Formentera.

Dell'Aglio, A. (1996): "L'argilla. Taranto", en E. Lippolis (ed.), I Greci in Occidente. Arte e artigianato in Magna Grecia, pp. 51-67. Milán, Electa.

Di Giuseppe, H. (2005): “Un confronto tra l'etruria settentrionale e meridionale dal punto di vista della ceramica a vernice nera". Papers of the British School at Rome, LXXIII: 31-84.

DRAE: Diccionario de la Lengua Española. 22 ${ }^{\mathrm{a}}$ edición. Real Academia Española de la Lengua. http:// lema.rae.es/drae/ [02.02.2011]

Duarte, F.; Garibo, J.; Mata, C.; Valor, J. P. y Vidal, X. (2000): "Tres centres de producció terrissera al territori de Kelin", en C. Mata y G. Pérez (eds.), Ibers. Agricultors, artesans i comerciants. III Reunió sobre Economia en el Món Ibèric. Saguntum-PLAV Extra 3, pp. 231-239. Valencia, Universidad de Valencia.

Duistermaat, K. (2007): The Pots and Potters of Assyria. Technology and organization of production, ceramic sequence, and vessel function at Late Bronze Age Tell Sabi Abyad, Syria. Tesis doctoral. Universidad de Leiden. https://openaccess.leidenuniv.nl/handle/1887/11416 [15.02.2011].

Ducci, S.; Carrera, F. y Pasini, D. (2006): "Collesalvetti (LI). La scoperta di un impianto produttivo d'età romana in località Guasticce-Ca' Lo Spelli”. Notiziario della Soprintendenza per $i$ Beni Archeologici della Toscana, pp. 242-243. I. Florencia, All'Insegna del Giglio.

Falsone, G. (1981): Struttura e origine orientale dei forni da vasaio di Mozia. Studi Monografici I. Palermo, Fondazione Giuseppe Withaker.

Fantar, M. (2010): "Remarques sur l'artisanat dans la cité punique de Kerkouane", en L'Africa Romana XVIII. I luoghi e le forme dei mestieri e della produzione nelle provincie africane /vol. 1, pp. 143-156. Olbia (2008), Roma, Carocci Editore.

Fernández Jurado, J. (1987): Tejada la Vieja: Una ciudad protohistórica. Huelva Arqueológica IX, 2 vol., Huelva, Servicio de Publicaciones de la Diputación.

Fernández Jurado, J. (1989): Tartessos y Huelva. Huelva Arqueológica X-XI, 3 vol. Huelva, Servicio de Publicaciones de la Diputación.
Gauckler, P. (1915): Necropoles puniques de Carthage, 2 vol. París, Auguste Picard.

García Alfonso, E. (1995): "La Antigüedad: Origen, desarrollo y disolución de un modelo urbano", en E. García, V. Martínez y A. Morgado (eds.), El Bajo Guadalteba (Málaga): Espacio y poblamiento. Una aproximación arqueológica a Teba y su entorno, pp. 91-209. Málaga, Centro de Ediciones Diputación Málaga.

García Alfonso, E. (1999): "Huertas de Peñarrubia (Campillos, Málaga): un asentamiento del Bronce FinalHierro Antiguo en el Valle del Guadalteba". Anuario Arqueológico de Andalucía/1994(III): 362-374.

García, E.; Morgado, A. y Roncal, E. (1995): "Valle del Guadalteba (Málaga). Una región idónea para el estudio del indigenismo precolonial". Revista de Arqueología CLXV: 32-41.

García Blánquez, L.A. (1995): "Pasico de San Pascual (Jumilla)", VI Jornadas de Arqueología Regional, p. 17. Murcia, Dirección General Cultura, Región de Murcia.

Giovagnetti, C. (1993): "La ceramica fina da mensa a vernice nera", en M.L. Stoppioni (ed.), Con la terra e con il fuoco. Fornaci romane del Riminese, pp. 115-124. Rimini, Guaraldi.

Giovagnetti, C. (1995): "La cerámica di Rimini repubblicana. La vernice nera di produzione lócale", en A. Calbi y G. Susini (dirs.), Pro poplo Arimenese, Atti del Convegno Internazionale Rimini antica. Una res pubblica fra terra e mare, pp. 327-468. Rimini (1993), Faenza, Stabilimento Grafico Fratelli Lega.

González, C.; Adroher, A. y López, A. (1995): "El yacimiento de Canto Tortoso (Gorafe, Granada): un enclave comercial del s. VI a. C. en el Guadiana Menor". Verdolay VII: 159-176.

Gran-Aymerich, J. (1991): Malaga phénicienne et punique. Recherches franco-espagnoles 1981-1988. París, Éditions Recherche sur les Civilizations.

Greco, C. (2000): "Solunto: nuovi dati della campagna di scavo 1997", en Atti del Convegno Terze Giornate Internazionali di Studi sull'Area Elima II, pp. 681-700. Gibellina-Erice-Contessa Entellina (1997), Pisa-Gibellina, Edizioni della Normale.

Greco, E. y Guzzo, P.G. (1978): "S. Maria del Cedro, Fraz. Marcellina". Notizie degli Scavi: 429-461.

Greco, E.; Luppino, S. y Schnapp, A. (eds.) (1989): Laos I-Scavi a Marcellina 1973-1975. Magna Graecia 5. Tarento, Istituto per la Storia e 1'Archeologia della Magna Grecia. 
Greco, G. y Pontrandolfo, A. (1990): Fratte. Un insediamento etruco-campano. Módena, Panini.

Guarducci, M. (1974): Epigrafia greca. Epigrafi di carattere privato, vol. III. Roma, Istituto Poligrafico e Zecca dello Stato.

Guglielmino, R. (1992): "Entella. La necropoli A: nuovi dati", en Atti delle Giornate Internazionali di Studi sull'Area Elima, pp. 371-378. Gibellina (1991) Pisa-Gibellina, Edizioni della Normale.

Guglielmino, R. (2000): “Entella: un'area artigianale extraurbana di età tardoarcaica", en Atti del Convegno Terze Giornate Internazionali di Studi sull'Area Elima II, pp. 701-713. Gibellina-Erice-Contessa Entellina (1997), Pisa-Gibellina, Edizioni della Normale.

Gutiérrez López, J.M. y Reinoso del Río, M.C. (2003): "Intervención arqueológica de urgencia en c/ Subida a la Iglesia, 55-57 (Villamartín, Cádiz). 2000”, Anuario Arqueológico de Andalucía/2000(III.1): 216-229.

Gutiérrez López, J.M. y Jiménez Pérez, C. (2010): “Excavación arqueológica de urgencia realizada en la U.E. 11, Villamartín (Cádiz)", Anuario Arqueológico de Andalucía/2006. Provincia de Cádiz, pp. 419427. http://www.juntadeandalucia/cultura/publico/ BBCC/Anuario_2006/Cadiz.pdf [20.02.2011]

Gutiérrez López, J.M.; Sáez Romero, A.M. y Reinoso, M.C. (2012): "Consideraciones sobre el origen, evolución y difusión peninsular de los prismas cerámicos: a propósito de algunos elementos de tecnología alfarera del asentamiento tartésico y turdetano de Torrevieja (Villamartín, Cádiz)". I Congreso Internacional de la Sociedad de Estudios sobre la Cerámica Antigua en Hispania. Hornos, talleres y focos de producción alfarera en Hispania, pp. 83112. Universidad de Cádiz (3-5 de marzo de 2011). Cádiz, Sociedad de Estudios de la Cerámica Antigua en Hispania.

Hasaki, E. (2002): Ceramic kilns in ancient greece: technology and organization of ceramic workshops. Tesis Doctoral. Universidad de Cincinnati. http://etd. ohiolink.edu/view.cgi?acc num=ucin 1023219003 [25.02.2011].

Hasaki, E. (2007): "Recensión de Cracolici, 2003". Bryn Mawr Classical Review, 2007.09.35. http:// bmcr.brynmawr.edu/2007/2007-09-35.html [25.02.2011].

Kalogeropoulou, A. (1970): "From the techniques of pottery". Athens Annals of Archaeology III: 429-434.

Kbiri Alaoui, M. (2007): Revisando Kuass (Asilah, Marruecos). Talleres cerámicos en un enclave fenicio, púnico y mauritano. Sagvntvm Extra 7. Valencia, Universidad de Valencia.

Killebrew, A. (1996): "Pottery kilns from Deir el-Balah and Tell Miqne-Ekron. Approaches to the study of firing technology during the Late Bronze and Iron Age periods in Canaan, Ancient Israel, Philistia and Phoenicia", en J. D. Seger (ed.), Retrieving the past. Essays on archaeological research and methodology. In honor of Gus W. Van Beek: 135-162. Mississippi, Cobb Institute of Archaeology, Mississippi State University.

Kourkoumelis, D. y Demesticha, S. (1997): "Outils de potier de l' atelier de Figareto à Corfu". Bulletin de Correspondance Hellénique 121(II): 553-571.

Laubenheimer, F.; Widemann, F.; Attas, M.; Fontes, P.; Gruel, K.; Leblanc, J. y Lleres, J. (1979): “Atelier de potier gallo-romain de Sallèles-d'Aude (Narbonne): le chargement du four B5", en B. Hoffmann y K. Goldmann (eds.), Internationales Symposion: Brenntechniken von Keramik und ihre Wiedergewinnung durch experimentelle Archäologie. Acta Praehistorica et Archaeologica (1978-1979) 9-10: 115-124. Berlin (1977), Berlín, Volker Spiess.

Lomba Maurandi, J. y Cano Gomariz, M. (2004): “El cabezo de la Fuente de El Murtal (Alhama): definición e interpretación de una fortificación de finales del s. VII a.C. e inicios del VI en la Rambla de Algeciras (Alhama de Murcia, Murcia)", Memorias de Arqueología XI, pp. 165-204. Murcia. Dirección General Cultura, Región de Murcia.

López Castro, J.L.; Martínez Hahnmüller, V.; Moya Cobos, L. y Pardo Barrionuevo, C. (2011): Baria I. Excavaciones arqueológicas en Villaricos. La excavación de urgencia de 1987. Almería, Universidad de Almería.

López Mullor, A.; Fierro, X.; Caixal, A. y Castellano, A. (1992): La primera Vilanova. L'establiment ibèric i la villa romana d'Arró, Darró o Adarró de Vilanova i la Geltrú. Síntesi dels resultats de les darreres recerques arqueolòiques $i$ històriques. Sant Sadurní, Institut d'Estudis Penedesencs.

López Palomo, L.A. (2008): Ategua (Córdoba): Protohistoria y romanización. Memoria de la actividad arqueológica puntual en el proyectado camino de acceso al yacimiento, campaña de 2004. Arqueología Monografías. Sevilla, Junta de Andalucía.

López Seguí, E. (1995): "El alfar ibérico de "El Arsenal" (Elche, Alicante)", en XXII Congreso Nacional de Arqueología II, pp. 231-234. Vigo (1993), Vigo, Junta de Galicia. 
López Seguí, E. (1997): "El alfar ibérico", en M. O1cina (ed.), La Illeta dels Banyets (El Campello, Alicante). Estudios de la Edad del Bronce y Época Ibérica, pp. 221-250. Alicante, Diputación Provincial.

López Seguí, E. (2000): “La alfarería ibérica en Alicante. Los alfares de La Illeta dels Banyets, La Alcudia y el Tossal de Manises", en C. Mata y G. Pérez (eds.), Ibers. Agricultors, artesans $i$ comerciants. III Reunió sobre Economia en el Món Ibèric. Saguntum-PLAV Extra 3, pp. 241-248. Valencia, Universidad de Valencia.

Lozano Pérez, L. (2006): "El centro artesanal iberorromano de La Maralaga (Sinarcas, Valencia)". Sagvntvm XXXVIII: 133-148.

Luzón Nogué, J.M. (1973): Excavaciones en Itálica. Estratigrafía en el Pajar de Artillo (Campaña 1970), Excavaciones Arqueológicas en España 78. Madrid, Ministerio de Cultura.

Mannoni, T. y Giannichedda, E. (1996): Archeologia della produzione. Turín, Einaudi.

Martín Córdoba, E.; Ramírez Sánchez, J.D. y Recio Ruiz, A. (2006): "Producción alfarera fenicio púnica en la costa de Vélez-Málaga (siglos VIII-V a.C.)". Mainake XXVIII: 257-287.

Martín Córdoba, E.; Ramírez Sánchez, J.D.; Recio Ruiz, A. y Moreno Aragüez, A. (2005): "Nuevos yacimientos fenicios en la costa de Vélez-Málaga (Málaga)". Ballix III: 7-46.

Martínez Alcalde, M. (2006): “Excavación arqueológica en la zona de La Alberca (Lorca, Murcia). Un horno alfarero de los siglos VII-VI a.C. y un centro comercial y militar de época tardopúnica y romana", $M e$ morias de Arqueología XIV, pp. 213-260. Murcia. Dirección General de Cultura, Región de Murcia.

Martínez Rodríguez, A. y Ponce García, J. (2004): "Aportaciones a los orígenes de la alfarería en Lorca a partir del horno ibérico hallado en la calle Alonso Fajardo, no 1". Memorias de Arqueología XI, pp. 379-390. Murcia. Dirección General de Cultura, Región de Murcia.

Martínez, A.; Castellano, J.J. y Sáez, A. (2000): “La producción de ánforas en el alfar ibérico de las Casillas del Cura (Venta del Moro, Valencia)", en C. Mata y G. Pérez (eds.), Ibers. Agricultors, artesans i comerciants. III Reunió sobre Economia en el Món Ibèric. Saguntum-PLAV Extra 3, pp. 225-229. Valencia, Universidad de Valencia.

Mascione, C. y Aprosio, M. (2003): "Elementi strutturali delle fornaci e distanziatori”, en G. Pucci y C. Mascione (eds.), Manifattura ceramica etrusco-romana a Chiusi. Il complesso produttivo di Marcianella, pp. 263-270. Bari, Edipuglia.

Mata Parreño, C. (1991): Los Villares (Caudete de las Fuentes, Valencia). Origen y evolución de la cultura ibérica. Serie Trabajos Varios del SIP 88. Valencia, Diputación Provincial.

Mendoza, A.; Molina, F.; Arteaga, O. y Aguayo, P. (1981): "Cerro de los Infantes (Pinos Puente, Granada). Ein Beitrag zur Bronce und Eisenzeit in Oberandalusien". Madrider Mitteilungen XXII: 171209.

Merker, G. (2006): Greek Tile Works at Corinth: The Site and the Finds. Hesperia Supplement 35. Princeton, American School of Classical Studies at Athens Publications.

Molinos, M.; Serrano, J.L. y Coba, B. (1990): “Excavaciones arqueológicas en el asentamiento de 'La Campiña'. Marmolejo, Jaén”. Anuario Arqueológico de Andalucía/1988(III): 197-203.

Monaco, M.C. (2000): Ergasteria: impianti artigianali ceramici ad Atene ed in Attica dal Protogeometrico alle soglie dell'Ellenismo. Roma, L'Erma di Bretschneider.

Morel, J.P. (1982): "La céramique à vernis noir de Carthage-Byrsa: nouvelles donnés et éléments de comparaison". Actes du Colloque sur la Céramique Antique: 43-76. Centre d'Etudes et de Documentation Archéologique de Carthage. Túnez, Publications de 1'Institut National d'Archéologie et d'Art.

Morel, J.P. (1998): "Su alcuni aspetti ceramologici di Spina", en F. Rebecchi (ed.), Spina e il delta padano. Riflessioni sul Catalogo e sulla Mostra ferrarese, pp. 85-100. Roma, L'Erma di Bretschneider.

Munzi, P. (2009): "Les fours de potiers et la production céramique à Laos (Calabre)", en J. P. Brun (ed.), Artisanats antiques d'Italie et de Gaule. Mélanges offerts à Francesca Buonaiuto, Collection du Centre Jean Bérard 32, pp. 265-283. Nápoles, Arte Tipografica.

Nijboer, A.J. (1998): From household production to workshops. Archaeological evidence for economic transformations, pre-monetary exchange and urbanisation in central Italy from 800 to $400 \mathrm{BC}$. Groningen, Drachten Donkel \& Donkel, University of Groningen.

Papadopoulos, J.K. (1989): “An Early Iron Age potter's kiln at Torone". Mediterranean Archeology III: 9-44.

Papadopoulos, J.K. (1992): " $\lambda \alpha \sigma \alpha v \alpha$, tuyères and kiln firing supports", Hesperia LXI: 203-221.

Papadopoulos, J.K. (2003): Ceramicus Redivivus. The Early Iron Age Potters' Field in the Area of the Classical Athenian Agora. Hesperia Supplement 
31. Princeton, American School of Classical Studies at Athens Publications.

Paribeni, E. (ed.) (1990): Etruscorum ante quam ligurum. La Versilia tra VII e III sec. a. C. (Catálogo de la exposición, Pietrasanta 1989). Pontedera, Artigiana Di Pie.

Parmeggiani, G. (1982): "Faenza, Piazza d'Armi”, en P. von Eles Masi (coord.), La Romagna tra VI e IV sec. a. C. La necropoli di Matericco e la protostoria romagnola (Catálogo de la exposición, Imola 1981), pp. 197-207. Bolonia, Bononia University Press.

Passelac, M. (1992): "Formes et techniques italiques dans les productions céramiques augustéennes du bassin de l'Aude: mise en évidence d'un groupe d'ateliers". Rei Cretariae Romanae Fautores Acta 31-32, pp. 207-229. Kallmünz, Verlag Michael Lassleben

Passelac, M. (2001): "Deux fours de potiers augustéens du Vicus Eburomagus (Bram, Aude)", en F. Laubenheimer (dir), 20 ans de recherches à Sallèles d'Aude, pp. 143-162. Besançon, Presses Universitaires Franc-Comtoises.

Perdiguero López, M. (1988): “Un horno alfarero de época ibérica en Aratispi (Cauche el Viejo, Antequera)". Jábega LXXIV: 3-14.

Peristeri, K.; Blonde, F.; Perreault, J.Y. y Brunet, M. (1985): "Thassos 1985". Athens Annals of Archaeology 18: 29-38.

Perreault, J.Y. (1990): “L'atelier de potier archaique de Phari (Thasos). La production de tuiles", en N. Winter (ed.), Proceedings of the International Conference on Greek Architectural Terracottas of the Classical and Hellenistic Periods. Hesperia Supplement 27, pp. 201-209. Princeton, American School of Classical Studies at Athens Publications.

Pons Mellado, E. (1983): “Acerca de unos hornos ibéricos en la Riera de Sant Simó (Mataró)". Laietania II-III: 185-200.

Pontrandolfo, A. (1996): "La ceramica", en M. Cipriani y F.Longo (eds.), I Greci in occidente. Poseidonia e i Lucani. Catálogo de la exposición, pp. 248-251. Paestum (1996), Nápoles-Milán, Electa.

Pritchard, J.B. (1975): Sarepta. A Preliminary Report on the Iron Age. Excavations of the University $\mathrm{Mu}$ seum of the University of Pennsylvania, 1970-72. Philadelphia, Universidad de Pennsylvania.

Puerta, D.; Burgos, A.; Pérez, C. y Lizcano, R. (2004): "Actuación arqueológica de urgencia realizada en el solar situado entre el Callejón de la Tahona y el Paseo de la Catedral de Guadix (Guadix, Granada)". Anuario Arqueológico de Andalucía/2001(III.1): 444-452.
Puig, A.M. (2006): "Els forns. Estructura i funcionament", en A. M. Puig y A. Martín (coords), La colònia grega de Rhode (Roses, Alt Empordà). Serie Monográfica 23, pp. 513-544. Girona, Museo de Arqueología de Cataluña-Girona.

Ramón Torres, J. (1991): Las ánforas púnicas de Ibiza. Trabajos del Museo Arqueológico de Ibiza 23. Ibiza, Govern Balear.

Ramón Torres, J. (1995): Las ánforas fenicio-púnicas del Mediterráneo Central y Occidental, Colección Instrumenta 2. Barcelona, Universitat de Barcelona.

Ramón Torres, J. (1997): FE-13. Un taller de alfarero de época púnica en Ses Figueretes (Eivissa). Trabajos del Museo Arqueológico de Ibiza 39. Ibiza, Museo Arqueológico de Ibiza y Formentera.

Ramón Torres, J. (1998): "Barrio industrial de la ciudad púnica de Eivissa: el taller AE-20", Misceláneas de Arqueología Ebusitana I. Trabajos del Museo Arqueológico de Ibiza 42, pp. 167-215. Ibiza, Museo Arqueológico de Ibiza y Formentera.

Ramón Torres, J. (2006): "La proyección comercial mediterránea y atlántica de los centros fenicios malagueños en época arcaica". Mainake XXVIII: 189-212.

Ramón, J.; Sáez, A.; Sáez Romero, A.M. y Muñoz, A. (2007): El taller alfarero tardoarcaico de Camposoto. Monografias de Arqueología 26. Sevilla, Junta de Andalucía.

Raya, I.; Burgos, A.; Fernández Aragón, I.; Lizcano, R. y Pérez, C. (2003): Guadix. Carta Arqueológica Municipal. Arqueología Monografías. Ciudad y Territorio. Sevilla, Junta de Andalucía.

Recio Ruiz, A. (1983): “Arroyo Hondo. Un alfar ibérico en Álora, provincia de Málaga". Mainake IV$\mathrm{V}: 133-172$.

Recio Ruiz, A. (2002): “Formaciones sociales ibéricas en Málaga". Mainake XXIV: 35-81.

Reinoso del Río, M.C. y Gutiérrez López, J.M. (2006): "Excavación de urgencia en Torrevieja Alta-U.E. 1 (Villamartín, Cádiz). Luces y sombras de una intervención arqueológica”. Anuario Arqueológico de Andalucía/2003(III.1): 209-224.

Ribas Bertrán, M. (1984): “Un taller d'ámphores a Mataró". Pyrenae XIX-XX: 281-285.

Rodríguez, A.; Chautón, H. y Duque, D.M. (2006): "Paisajes rurales protohistóricos en el Guadiana Medio: Los Caños (Zafra, Badajoz)". Revista Portuguesa de Arqueologia IX(1): 71-113.

Rodríguez Martín, F. G. (1996): Materiales de un alfar emeritense: paredes finas, lucernas, sigillatas y terracotas. Mérida, Museo Nacional de Arte Romano. 
Roebuck, C. (1951): The Asklepieion and Lerna. Corinth XIV. American School of Classical Studies at Athens. Princeton, American School of Classical Studies Publications.

Ros Sala, M.M. (1989): Dinámica urbanística y cultura material del hierro antiguo en el Valle del Guadalentín. Murcia, Colegio Oficial de Arquitectos.

Rosser Limiñana, P. y Fuentes, C. (2007): Tossal de les Basses. Seis mil años de historia de Alicante. Alicante, Ayuntamiento de Alicante.

Rosser Limiñana, P. y Pérez Burgos, J.M. (2004): “La zona periurbana del poblado. La pista de circulación, el horno cerámico y la necrópolis de incineración", en P. Rosser, J. Elayi y J. M. Pérez (eds.), El Cerro de las Balsas y el Chinchorro: una aproximación a la arqueología del poblamiento prehistórico e ibérico de la Albufereta de Alicante. LQNT. Monográfico 2, pp. 177-194. Alicante, Ayuntamiento de Alicante.

Ruescas Pareja, V.E. y Ramírez Sánchez, J. D. (2010): "Intervención arqueológica preventiva con sondeos en la parcela $\mathrm{n}^{\circ} 28$ de la urbanización Cerro y Mar, yacimiento Las Chorreras, Mezquitilla, Vélez-Málaga (Málaga)". Anuario Arqueológico de Andalucia/2006. Provincia de Málaga: 3209-3222. http:// www.juntadeandalucia/cultura/publico/BBCC/ Anuario_2006/Malaga.pdf [20.02.2011]

Ruiz Mata, D. (1998): “Turdetanos: origen, territorio y delimitación del tiempo histórico". Revista de Estudios Ibéricos III: 153-221.

Sáez Romero, A.M. (2004): "El alfar tardopúnico de Torre Alta. Resultados de las excavaciones de 20022003". Actas del Congreso Internacional Figlinae Baeticae. Talleres alfareros y producciones cerámicas en la Bética romana (ss. II a.C.-VII d.C.). BAR International Series 1266(II), pp. 699-712. Oxford, Hadrian Books.

Sáez Romero, A.M. (2005): “Aproximación a la tipología de la cerámica común púnico-gadirita de los ss. III-II". Spal 14: 145-177. http://dx.doi. org/10.12795/spal.2005.114.06

Sáez Romero, A.M. (2008): La producción cerámica en Gadir en época tardopúnica (siglos -III/ -I). BAR International Series 1812, 2 vol. Oxford, Hadrian Books.

Sáez Romero, A.M.; Montero, A.I. y Díaz, J.J. (2005): "La producción alfarera de época púnica en Gadir (ss. VI-IV a.n.e.)", en A. Blanco, C. Cancelo y A. Esparza (eds.), Bronce Final y Edad de Hierro en la Península Ibérica. Encuentro de Jóvenes Investigadores. Colección Aquilafuente 86, pp. 479-501. Salamanca, Universidad de Salamanca, Fundación Duques de Soria.

Sánchez, C. (2009): "Production et consommation des céramiques communes de la colonie romaine de Narbonne (IIe av./Ve de n. è.)", en M. Pasqualini (dir.), Les céramiques communes d'Italie et de Narbonnaise. Structures de production, typologies et contextes inédits (IIe s. av. J.-C.-IIIe s. apr. J-C.). Collection du Centre Jean Bérard 30, pp. 471-492. Nápoles, Arte Tipográfica.

Sánchez, G.; Gonzálvez, J.M. y Morer, J. (1995): “Dos assentaments rurals indígenas arran del camí de Parpers". Lauro X: 3-10.

Sanciu, A. (1995): "Nuove acquisizioni su Olbia punica: una fornace", en Actas del III Congreso Internacional de Estudios Fenicios y Púnicos vol. II, pp. 366-375. Túnez (1991), Túnez, Institut National du Patrimoine.

Sassatelli, G. (1993): "La funzione economica e produttiva: merci, scambi, artigianato", en F. Berti y P. G. Guzzo (ed.), Spina. Storia di una città tra Greci ed Etruschi: 179-217. Ferrara, Maurizio Tosi Editore.

Serritella, A. (2011): "La fornace", en A. Pontrandolfo y A. Santoriello (eds.), Fratte. L'area a vocazione artigianale e produttiva. Ergasteria 1: 139-143. Salerno, Universidad de Salerno.

Schubart, H. (1987): "Hallazgos fenicios y del Bronce Final en la desembocadura del río Guadiaro (Cádiz)". Anuario Arqueológico de Andalucía'1986(II): 200-227.

Stazio, A. (1965): "L'attività archeologica in Puglia", en Atti del XV Convegno Internazionale di Studi sulla Magna Grecia, pp. 247-248. Nápoles, Arte Tipografica.

Tremoleda, J. (2000): Industria y artesanado cerámico de época romana en el nordeste de Cataluña (época augustea y altoimperial). BAR International Series 835. Oxford, Hadrian Books.

Vegas, M. (1998): “Alfares arcaicos en Cartago", en Cartago Fenicio-Púnica. Las excavaciones alemanas en Cartago 1975-19970. Cuadernos de Arqueología Mediterránea 4: 147-164. Barcelona, Bellaterra. 